Supporting Information

\title{
Modulation of Pyrene Fluorescence in DNA probes Depends upon the Nature of the Conformationally Restricted Nucleotide
}

\author{
Dmytro Honcharenko, Chuanzheng Zhou and Jyoti Chattopadhyaya* \\ Department of Bioorganic Chemistry, Box 581, Biomedical Center, \\ Uppsala University, SE-75123 Uppsala, Sweden \\ jyoti@boc.uu.se
}

\section{Table of Contents:}

General Experimental Methods

Experimental Section S1. Synthesis of 2'- $N$-(pyren-1-yl)carbonyl-aza-ENA thymidine and its phosphoramidite building block

Table S1. MALDI-TOF MS of synthesized oligonucleotides

Figure S1. Absorption spectra of (A) fully deprotected Aze-pyr modified nucleoside 3 and (B) fully deprotected Aza-ENA-pyr modified nucleoside 8

Figure S2. Fluorescence emission spectra of (A) Aze-pyr modified ODN 2 and (B) Aza-ENA-pyr modified ODN 5 and the corresponding duplexes with complementary DNA 2 or

RNA 1 .S9

Figure S3. Fluorescence emission spectra of (A) Aze-pyr modified ODN 3 and (B) Aza-ENA-pyr

\footnotetext{
* Corresponding author
} 
modified ODN 6 and the corresponding duplexes with complementary DNA 2 or

RNA 1

Figure S4 - S5. Area vs. $A_{340}$ curves of fully deprotected Aze-pyr modified nucleoside 3 and Aza-ENA-pyr modified nucleoside $\mathbf{8}$ in thermal denaturation buffer for determination of the emission quantum yields. S11-S12

Figure S6. The emission spectra showing the temperature dependent fluorescence changes for the duplex formed by Aze-pyr modified ODN 1 and complementary RNA 1

Figure S7. The emission spectra showing the temperature dependent fluorescence changes for the duplex formed by Aza-ENA-pyr modified ODN 4 and complementary DNA 2

Figure S8 - S11. Fluorescence emission spectra of Aze-pyr modified ODNs 7-10 and Aze-pyr modified ODNs 11-14 and the corresponding duplexes with complementary DNA or RNA targets. S15-S18

Figure S12. Expanded CD spectra for the duplexes formed by Aze-pyr modified ODN 1 and AzaENA-pyr modified ODN 4 with complementary DNA 2 , RNA 1 and RNA 2 containing (G) mismatch

Figure S13. CD spectra (A) for the native DNA 1/DNA 2 and Aze-pyr modified ODNs 1-3/DNA 2 duplexes and (B) for the native DNA 1/RNA 1, ODNs 1-3/RNA 1 and ODNs 1-3/RNA $\mathbf{2}$ containing single base $(\mathbf{G})$ mismatch.

Figure S14. CD spectra (A) for the native DNA 1/DNA 2 and Aza-ENA-pyr modified ODNs 4-6/DNA 2 duplexes and (B) for the native DNA 1/RNA 1, ODNs 4-6/RNA 1 and ODNs 4-6/RNA 2 containing single base $(\mathbf{G})$ mismatch $\mathrm{S} 21$

Figure S15. Expanded CD spectra for Aze-pyr modified ODN 1 and Aza-ENA-pyr modified ODN 4 and for their corresponding duplexes with (A) complementary DNA 2 and (B) complementary RNA 1 S22

Figures S16 - S19. ${ }^{1} \mathrm{H}$ NMR spectra of compounds $2-4$ and 7 . S23-S26 
Figures S20 - S27. ${ }^{13} \mathrm{C}$ NMR spectra of compounds 1-4, 6-9........................................S27 - S34

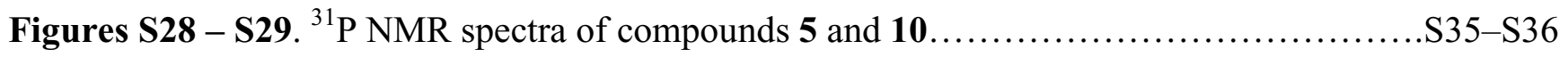




\section{Experimental Section S1}

General Experimental Methods. Chromatographic separations were performed on G60 silica gel. Thin layer chromatography (TLC) was performed on pre-coated silica gel $60 \mathrm{~F}_{254}$ glass-backed plates. ${ }^{13} \mathrm{C}$ NMR spectra were recorded at $67.9 \mathrm{MHz}$ using the central peak of $\mathrm{CDCl}_{3}(76.9 \mathrm{ppm}), \mathrm{CD}_{3} \mathrm{OD}$ (49.3 ppm) or DMSO- $d_{6}(39.6 \mathrm{ppm})$ as internal standards. ${ }^{31} \mathrm{P}$ NMR spectra were recorded at 109.4 MHz using $85 \%$ phosphoric acid as external standard. Chemical shifts are reported in ppm $(\delta$ scale $)$. Compound names for the bicyclic structures are given according to the von Baeyer nomenclature. MALDI-TOF MS were recorded in positive ion mode for the synthesized compounds and oligonucleotides. The mass spectrometer was externally calibrated with a peptide mixture using alphacyano-4-hydroxycinnamic acids as matrix. Thermal denaturation experiments and absorption spectra measurements were performed on a UV/VIS spectrometer equipped with temperature controller. Fluorescence spectra measurements were carried out on a luminescence spectrometer using temperature controller. The CD spectra were recorded using a spectropolarimeter.

\section{(1R,5R,7R,8S)-5-Benzyloxymethyl-8-benzyloxy-2- $N$-(pyren-1-ylcarbonyl)-7-(thymin-1-yl)-2-}

aza-6-oxabicyclo[3.2.1]octane (7). To a stirred solution of pyrenecarboxylic acid (0.076 g, $0.31 \mathrm{mmol})$ in $N, N$-dimethylformamide $(4 \mathrm{~mL})$ were added PyBOP $(0.168 \mathrm{~g}, 0.32 \mathrm{mmol})$, diisopropylethylamine $(0.052 \mathrm{~mL}, 0.3 \mathrm{mmol})$ and nucleoside $6(0.1 \mathrm{~g}, 0.22 \mathrm{mmol})$. The reaction mixture was stirred for $2 \mathrm{~h}$ at room temperature. Saturated aqueous $\mathrm{NaHCO}_{3}$ solution $(5 \mathrm{~mL})$ was added and the mixture was extracted with dichloromethane $(3 \times 25 \mathrm{~mL})$. The organic layer was dried over anhydrous $\mathrm{MgSO}_{4}$, filtered and concentrated in vacuo. The crude product was purified by silica gel column chromatography (0-4\% methanol in dichloromethane, v/v) to give $7(0.134 \mathrm{~g}, 0.19 \mathrm{mmol}, 90 \%)$ as a mixture of diastereomers. $R_{f}=0.35\left[96: 4 \mathrm{CH}_{2} \mathrm{Cl}_{2} / \mathrm{CH}_{3} \mathrm{OH}(\mathrm{v} / \mathrm{v})\right]$. MALDI-TOF $m / z:[\mathrm{M}+\mathrm{H}]^{+}$found, 692.4; calcd, 692.3. ${ }^{13} \mathrm{C}$ NMR (67.9 $\left.\mathrm{MHz}, \mathrm{CDCl}_{3}\right) \delta: 170.8,170.2,164.1,163.5,162.5,150.0,149.9$, 
$137.1,137.0,135.4,134.9,131.6,131.5,130.9,130.8,130.5,130.4,129.3,129.2,128.8,128.5,128.4$, $128.0,127.9,127.7,127.6,127.3,126.9,126.8,126.1,126.0,125.5,125.3,125.1,124.7,124.5,124.2$, $124.1,124.0,123.7,123.5,123.4,109.9,107.8,86.1,84.6,84.2,73.4,73.2,72.9,72.4,72.2,71.6,71.3$, $69.6,69.3,67.3,62.4,56.1,56.0,48.1,48.0,41.6,41.1,36.3,35.9,31.3,29.5,27.3,26.8,26.3,25.8$, 25.7, 11.9, 11.5.

(1R,5R,7R,8S)-5,8-Hydroxy-2-N-(pyren-1-ylcarbonyl)-7-(thymin-1-yl)-2-aza-6-

oxabicyclo[3.2.1]octane (8). Compound 7 (0.134 g, $0.19 \mathrm{mmol})$ was dissolved in $5 \mathrm{~mL}$ of methanol, $\mathrm{Pd}(\mathrm{OH})_{2}$ on charcoal $(20 \%$ moist, $0.04 \mathrm{~g})$ and ammonium formate $(0.15 \mathrm{~g}, 2.43 \mathrm{mmol})$ were added to the solution of nucleoside. The resulting suspension was heated under reflux for $36 \mathrm{~h}$. The reaction mixture was filtered through silica gel bed and washed with hot methanol $(15 \mathrm{~mL})$. The filtrate was concentrated to dryness in vacuo and purified by silica gel column chromatography (0-8\% methanol in dichloromethane, v/v) to afford $8(0.081 \mathrm{~g}, 0.16 \mathrm{mmol}, 82 \%) . R_{f}=0.35\left[90: 10 \mathrm{CH}_{2} \mathrm{Cl}_{2} / \mathrm{CH}_{3} \mathrm{OH}(\mathrm{v} / \mathrm{v})\right]$. MALDI-TOF $m / z:[\mathrm{M}+\mathrm{H}]^{+}$found, 512.4; calcd, 512.2. ${ }^{13} \mathrm{C}$ NMR (67.9 MHz, DMSO- $\left.d_{6}\right) \delta: 169.7$, $168.8,164.3,163.6,150.3,149.6,135.7,135.2,131.0,130.9,130.7,130.6,130.4,130.2,128.3,128.0$, $127.8,127.6,127.3,127.2,126.8,126.6,126.4,126.3,125.8,125.7,125.6,125.4,125.1,125.0,124.9$, $124.7,124.6,124.0,123.9,123.8,123.7,108.0,107.8,107.6,85.6,85.3,85.2,64.3,64.0,63.4,63.2$, $63.0,60.9,58.5,54.9,42.0,41.5,36.1,35.6,34.7,27.3,26.0,25.3,25.0,12.5,12.3$.

(1R,5R,7R,8S)-5-(4,4'-Di-methoxytrityloxymethyl)-8-hydroxy-2-N-(pyren-1-ylcarbonyl)-7(thymin-1-yl)-2-aza-6-oxabicyclo[3.2.1]octane (9). Nucleoside 8 (0.05 g, $0.1 \mathrm{mmol})$ was coevaporated with anhydrous pyridine $(3 \times 2 \mathrm{~mL})$ and dissolved in $2 \mathrm{~mL}$ of the same solvent, and 4,4'dimethoxytrityl chloride $(0.057 \mathrm{~g}, 0.17 \mathrm{mmol})$ was added and stirred at room temperature for $32 \mathrm{~h}$ under nitrogen atmosphere. The reaction mixture was poured into cold saturated aqueous $\mathrm{NaHCO}_{3}$ solution $(5 \mathrm{~mL})$ and extracted with dichloromethane $(3 \times 20 \mathrm{~mL})$. The organic layer was dried over anhydrous $\mathrm{MgSO}_{4}$, filtered and evaporated under reduced pressure followed by co-evaporation with toluene $(2 \times 10 \mathrm{~mL})$. The crude product was purified by silica gel column chromatography $(0-4 \%$ 
methanol in dichloromethane $(\mathrm{v} / \mathrm{v})$, containing $1 \%$ pyridine $)$ to give $9(0.06 \mathrm{~g}, 0.074 \mathrm{mmol}, 76 \%) . R_{f}=$ $0.22\left[96: 4 \mathrm{CH}_{2} \mathrm{Cl}_{2} / \mathrm{CH}_{3} \mathrm{OH}(\mathrm{v} / \mathrm{v})\right]$. MALDI-TOF $m / z:[\mathrm{M}+\mathrm{H}]^{+}$found, 814.2; calcd, 814.3. ${ }^{13} \mathrm{C}$ NMR (67.9 $\mathrm{MHz}, \mathrm{CDCl}_{3}$ plus DABCO) $\delta: 171.3,171.2,164.7,163.3,158.5,150.2,149.7,144.3,144.0$, $135.5,135.2,134.8,131.7,131.1,130.8,130.6,130.0,129.1,128.9,128.1,127.9,127.7,127.0,126.8$, $126.3,126.2,125.7,125.5,124.6,124.3,123.5,113.2,110.3,110.0,86.7,86.4,85.9,85.7,85.4,85.1$, $68.0,66.6,65.2,64.1,63.5,63.3,59.4,59.3,55.1,51.2,46.1,43.2,42.2,41.8,40.6,36.0,34.9,29.6$, $27.1,26.7,26.3,25.5,12.1,11.7$.

(1R,5R,7R,8S)-8-(2-Cyanoethoxy(diisopropylamino)-phosphinoxy)-5-(4,4'-dimethoxytrityloxymethyl)-2-N-(pyren-1-ylcarbonyl)-7-(thymin-1-yl)-2-aza-6oxabicyclo[3.2.1]octane (10). Nucleoside $9(0.12 \mathrm{~g}, 0.15 \mathrm{mmol})$ was dissolved in $2 \mathrm{~mL}$ of dry THF, diisopropylethylamine $(0.13 \mathrm{~mL}, 0.74 \mathrm{mmol})$ was added at $0{ }^{\circ} \mathrm{C}$ under a nitrogen atmosphere followed by 2-cyanoethyl- $N, N$-diisopropylphosphoramidochloridite $(0.066 \mathrm{~mL}, 0.29 \mathrm{mmol})$. After $30 \mathrm{~min}$ the reaction was warmed to room temperature and stirred overnight. Methanol $(0.2 \mathrm{~mL})$ was added and stirring was continued for $10 \mathrm{~min}$, after reaction mixture was poured into saturated aqueous $\mathrm{NaHCO}_{3}$ solution $(7 \mathrm{~mL})$ and extracted with freshly distilled dichloromethane $(3 \times 20 \mathrm{~mL})$. The organic layer was dried over anhydrous $\mathrm{MgSO}_{4}$, filtered and concentrated in vacuo. The crude residue was purified by silica gel column chromatography $\left(20-70 \% \mathrm{CH}_{2} \mathrm{Cl}_{2}\right.$ in cyclohexane containing $\left.2 \% \mathrm{Et}{ }_{3} \mathrm{~N}\right)$ to afford $10(0.11 \mathrm{~g}, 0.11 \mathrm{mmol}, 73 \%)$ as a mixture of isomers. $R_{f}=0.34\left[96: 4 \mathrm{CH}_{2} \mathrm{Cl}_{2} / \mathrm{CH}_{3} \mathrm{OH}(\mathrm{v} / \mathrm{v})\right]$. MALDITOF $m / z:[\mathrm{M}+\mathrm{H}]^{+}$found, 1014.4; calcd, 1014.4. ${ }^{31} \mathrm{P}$ NMR $\left(67.9 \mathrm{MHz}, \mathrm{CDCl}_{3}\right) \delta: 153.3,151.6,150.1$, 149.5 . 
Table S1. MALDI-TOF MS of synthesized oligonucleotides.

\begin{tabular}{|c|c|c|c|}
\hline ONs & Oligonucleotides & Found $m / z:[\mathbf{M}+\mathbf{H}]^{+}$ & Calcd $m / z:[\mathbf{M}+\mathbf{H}]^{+}$ \\
\hline ODN 1 & 5'-dCTTCAXTTTTTCTTC & $4705.6^{a}$ & 4703.8 \\
\hline ODN 2 & 5'-dCТTCATTХTTTCTTC & 4703.5 & 4703.8 \\
\hline ODN 3 & 5'-dCTTCATTTTХTCTTC & $4705.5^{a}$ & 4703.8 \\
\hline ODN 4 & 5'-dCTTCAYTTTTTCTTC & $4719.0^{a}$ & 4717.8 \\
\hline ODN 5 & 5'-dCTTCATTYTTTCTTC & $4719.1^{a}$ & 4717.8 \\
\hline ODN 6 & 5'-dCTTCATTTTYTCTTC & $4719.2^{a}$ & 4717.8 \\
\hline ODN 7 & 5'-dCTTCAХCTTTTCTTC & 4688.1 & 4688.8 \\
\hline ODN 8 & 5'-dCTTCAХATTTTCTTC & 4712.1 & 4712.8 \\
\hline ODN 9 & 5'-dCTTCAXGTTTTCTTC & 4727.8 & 4728.8 \\
\hline ODN 10 & 5'-dCTTCGXGTTTTCTTC & 4744.1 & 4744.8 \\
\hline ODN 11 & 5'-dCTTCAYCTTTTCTTC & 4702.2 & 4702.8 \\
\hline ODN 12 & 5'-dCTTCAYATTTTCTTC & 4725.9 & 4726.8 \\
\hline ODN 13 & 5'-dCTTCAYGTTTTCTTC & 4742.1 & 4742.8 \\
\hline ODN 14 & 5'-dCTTCGYGTTTTCTTC & 4758.2 & 4758.8 \\
\hline DNA 1 & 5'-dCTTCATTTTTTCTTC & 4448.6 & 4448.7 \\
\hline DNA 2 & 5'-dGAAGAAAAAATGAAG & 4689.8 & 4689.9 \\
\hline DNA 3 & 5'-dGAAGAAAAGATGAAG & 4705.0 & 4705.9 \\
\hline DNA 4 & 5'-dGAAGAAAATATGAAG & 4680.1 & 4680.9 \\
\hline DNA 5 & 5'-dGAAGAAAACATGAAG & 4665.1 & 4665.9 \\
\hline DNA 6 & 5'-dGAAGAAAACACGAAG & 4649.7 & 4650.9 \\
\hline RNA 1 & 5'-rGAAGAAAAAAUGAAG & $4917.4^{a}$ & 4915.8 \\
\hline RNA 2 & 5'-rGAAGAAAAA $\underline{\text { GGAAG }}$ & 4932.3 & 4931.8 \\
\hline RNA 3 & 5'-rGAAGAAAAA $\underline{\mathbf{U} U G A A G}$ & 4893.0 & 4892.8 \\
\hline RNA 4 & 5'-rGAAGAAAAACEUAAG & 4891.9 & 4891.8 \\
\hline RNA 5 & 5'-rGAAGAAAAGAUGAAG & 4931.5 & 4931.8 \\
\hline RNA 6 & 5'-rGAAGAAAAUAUGAAG & 4892.0 & 4892.8 \\
\hline RNA 7 & 5'-rGAAGAAAACAUGAAG & 4891.2 & 4891.8 \\
\hline RNA 8 & 5'-rGAAGAAAACACGAAG & 4890.4 & 4890.8 \\
\hline
\end{tabular}

${ }^{a}[\mathrm{M}+2 \mathrm{H}]^{+}$. The mismatch bases in RNA sequences are indicated by the bold and underline fonts. 

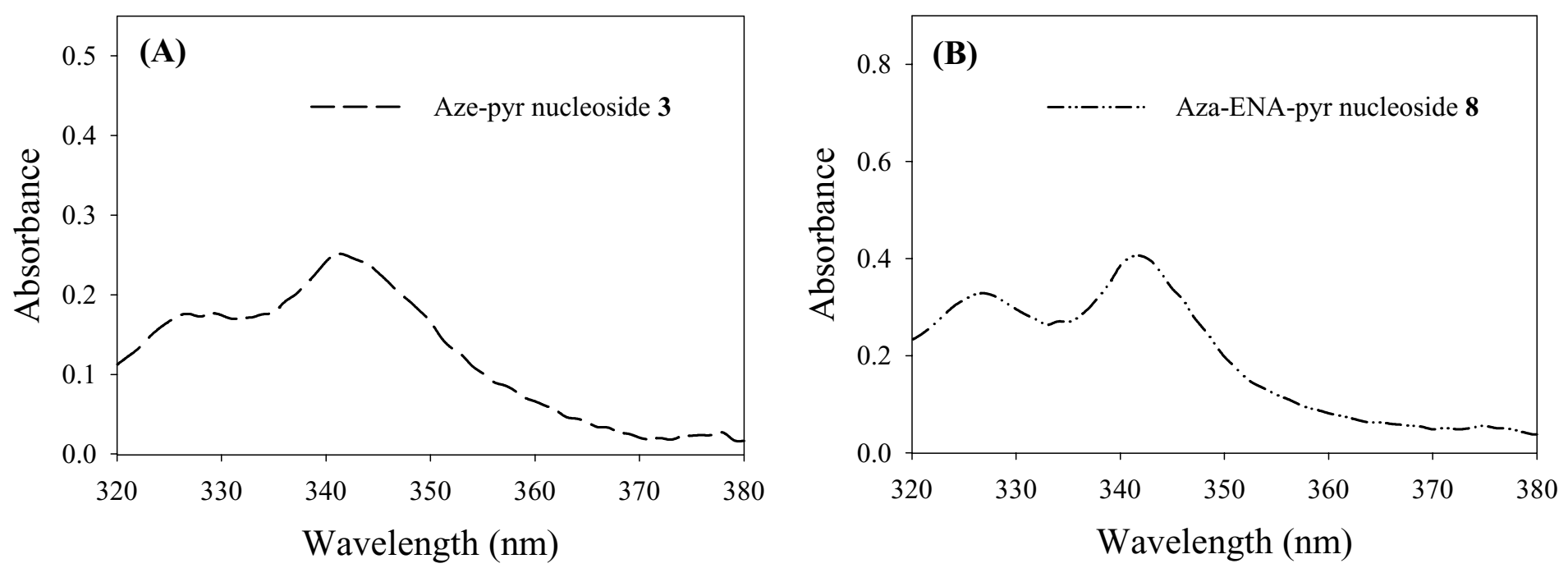

Figure S1. Absorption spectra of (A) fully deprotected Aze-pyr modified nucleoside 3 and (B) fully deprotected Aza-ENA-pyr modified nucleoside 8. The structures of nucleosides $\mathbf{3}$ and $\mathbf{8}$ are shown in Figure 1. 

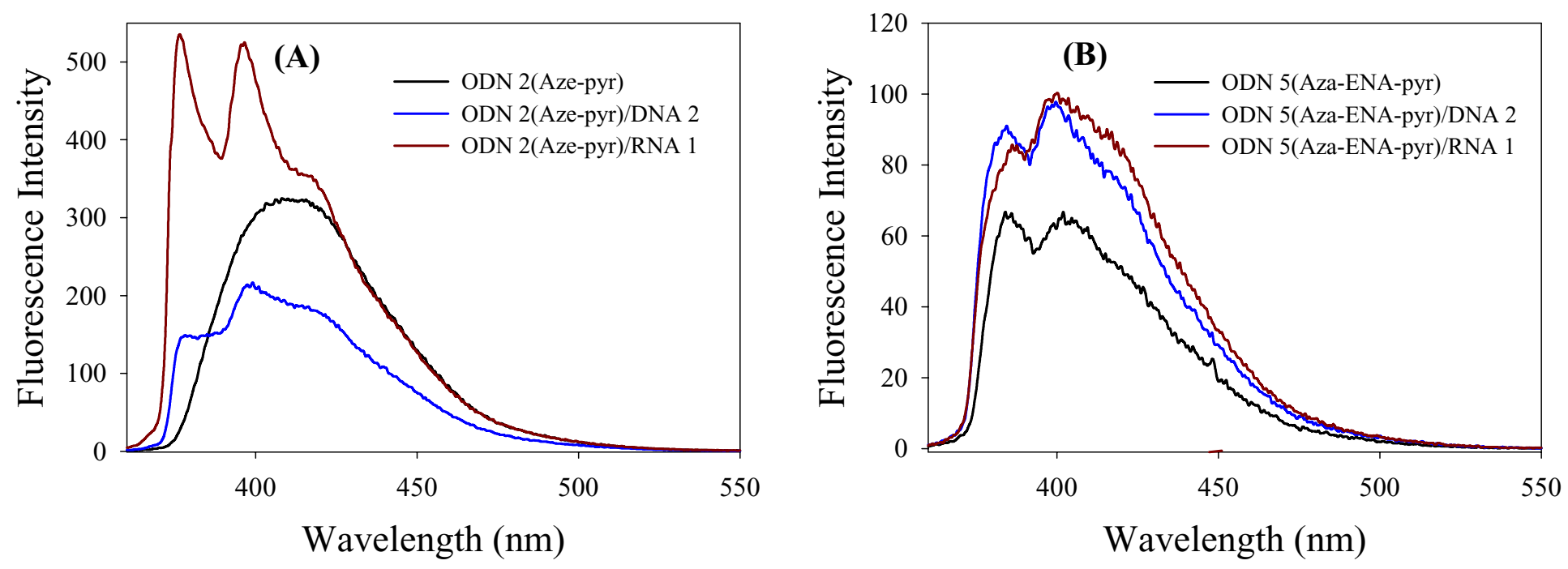

Figure S2. Fluorescence emission spectra of (A) Aze-pyr modified ODN 2 and (B) Aza-ENA-pyr modified ODN 5 and the corresponding duplexes with complementary DNA 2 or RNA 1 targets. Spectra were recorded at total strand concentration of $0.8 \mu \mathrm{M}$ and with an excitation wavelength of 340 nm. 

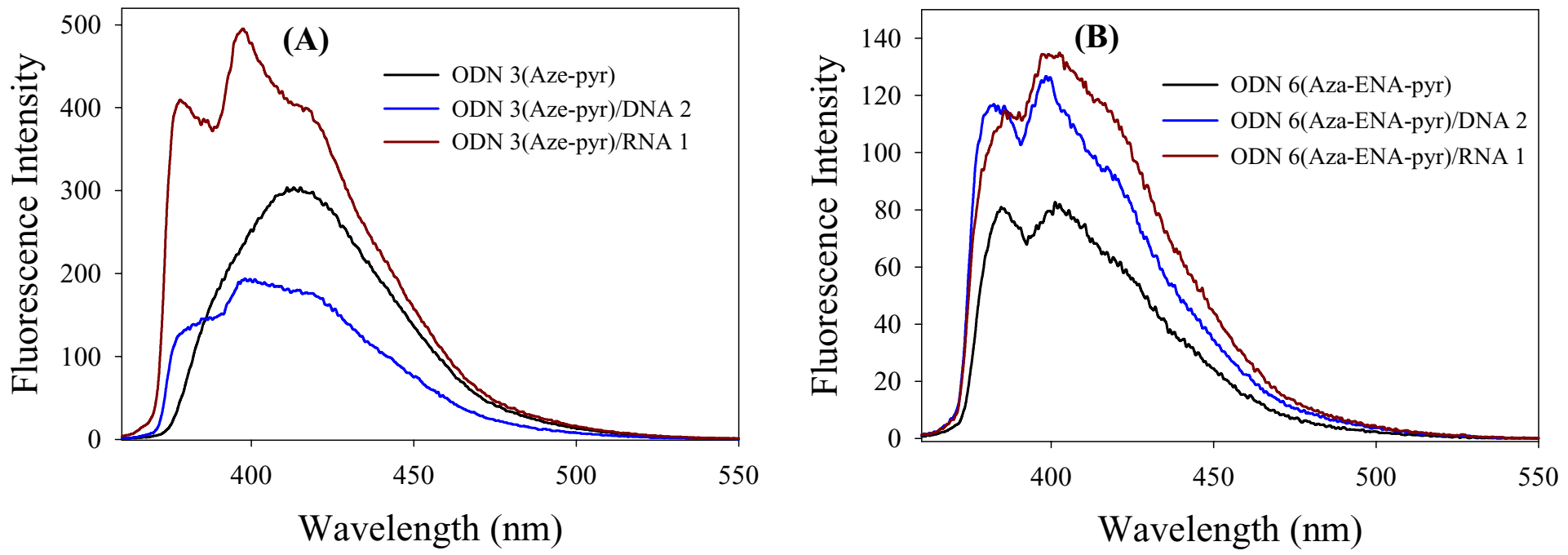

Figure S3. Fluorescence emission spectra of (A) Aze-pyr modified ODN 3 and (B) Aza-ENA-pyr modified ODN 6 and the corresponding duplexes with complementary DNA 2 or RNA 1 targets. Spectra were recorded at total strand concentration of $0.8 \mu \mathrm{M}$ and with an excitation wavelength of 340 nm. 


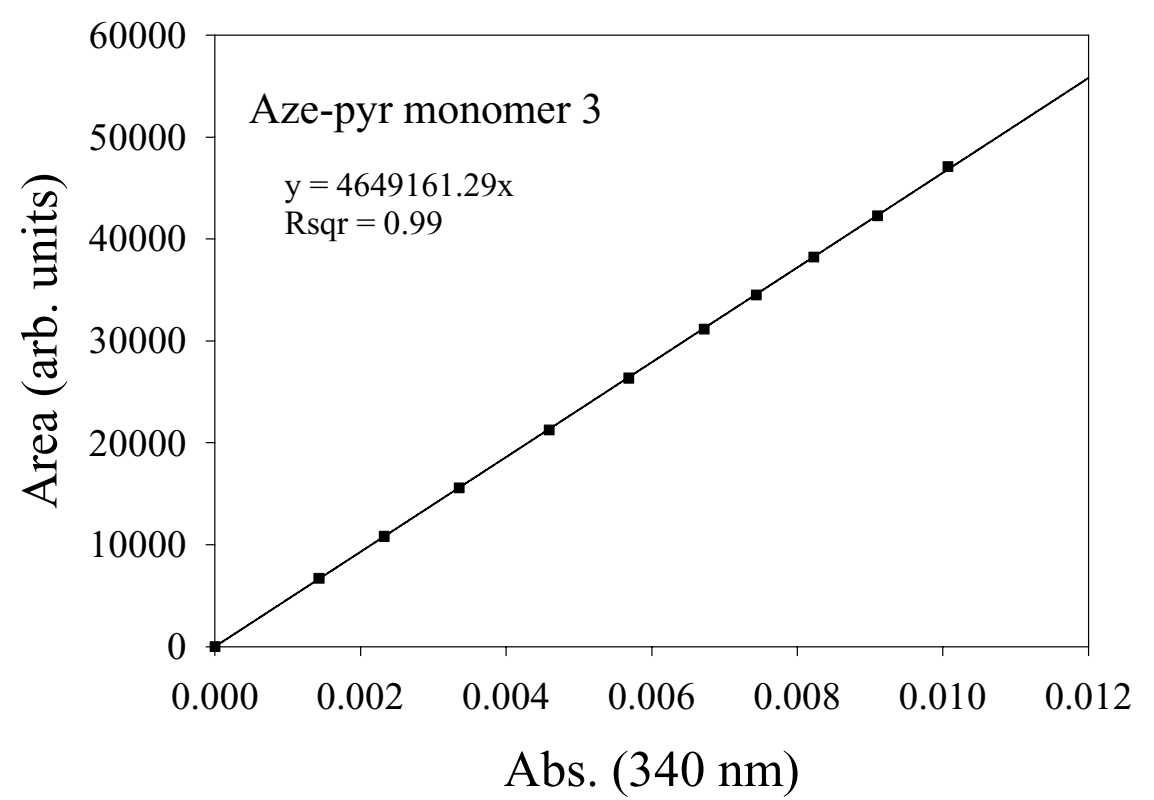

Figure S4. Area vs. $A_{340}$ curve of fully deprotected Aze-pyr modified nucleoside 3 [Aze-pyr monomer 3] in thermal denaturation buffer for determination of the emission quantum yield ${ }^{1}$.

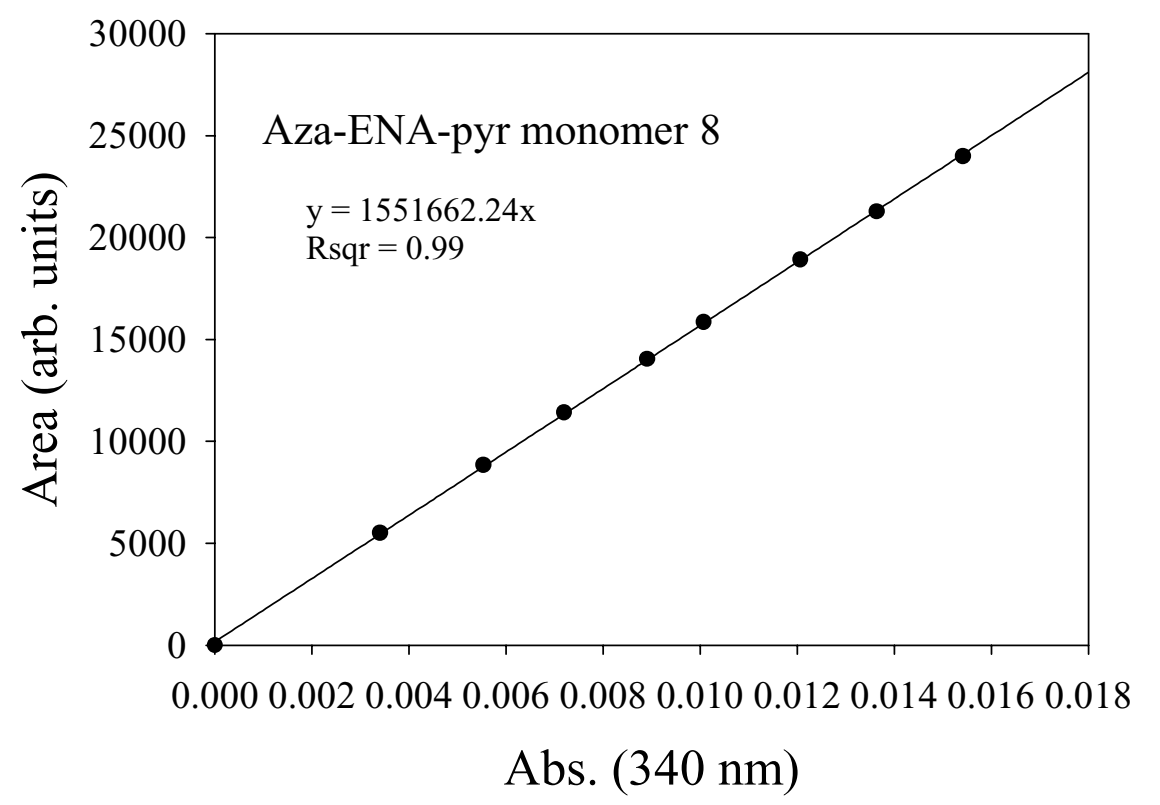

Figure S5. Area vs. $A_{340}$ curve of fully deprotected Aza-ENA-pyr modified nucleoside 8 [Aza-ENApyr monomer 8 ] in thermal denaturation buffer for determination of the emission quantum yield ${ }^{1}$.

${ }^{1}$ The fluorescence quantum yields $\left(\boldsymbol{\Phi}_{\mathrm{F}}\right)$ of fully deprotected nucleosides $\mathbf{3}$ and $\mathbf{8}$ was determined according to: 
$\boldsymbol{\Phi}_{\mathrm{F}}($ monomer $)=\left[A_{340}(\mathrm{PBA}) / F(\mathrm{PBA})\right] \times[1 / \alpha($ monomer $)] \times\left[n\left(\mathrm{H}_{2} \mathrm{O}\right) / n(\mathrm{MeOH})\right]^{2} \times \boldsymbol{\Phi}_{\mathrm{F}}(\mathrm{PBA})$

where $\boldsymbol{\Phi}_{\mathrm{F}}(\mathrm{PBA})$ is the fluorescence quantum yield of pyrenebutanoic acid (PBA) as a reference with a known $\boldsymbol{\Phi}_{\mathrm{F}}$ of $0.065 ; A_{340}$ is absorbance of the PBA at the excitation wavelength $(340 \mathrm{~nm}) ; F$ is the area of the fluorescence emission spectra of the PBA from 360 to $590 \mathrm{~nm}$; $\alpha$ (monomer) is the slope of the fluorescence emission area vs. $A_{340}$ calibration curve for the 2 '- $N$-(pyren-1-yl)carbonyl-1',2'azetidine nucleoside 3 or 2'- $N$-(pyren-1-yl)carbonyl-2'-aza-ENA nucleoside $8 ; n\left(\mathrm{H}_{2} \mathrm{O}\right)$ and $n(\mathrm{MeOH})$ are the refractive indexes of water (1.3328) and methanol (1.3288). 


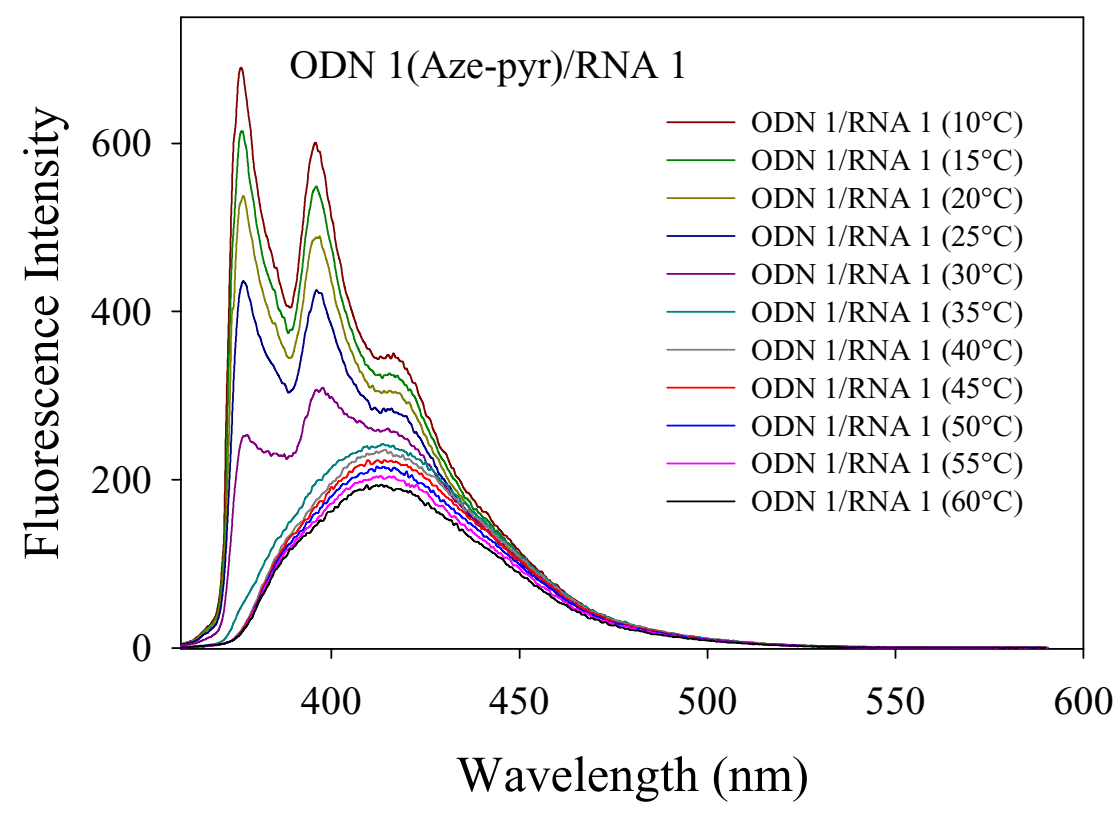

Figure S6. The emission spectra showing temperature dependent fluorescence changes for the duplex formed by Aze-pyr modified ODN 1 and complementary RNA. Spectra were recorded at total strand concentration of $0.8 \mu \mathrm{M}$ and with an excitation wavelength of $340 \mathrm{~nm}$. 


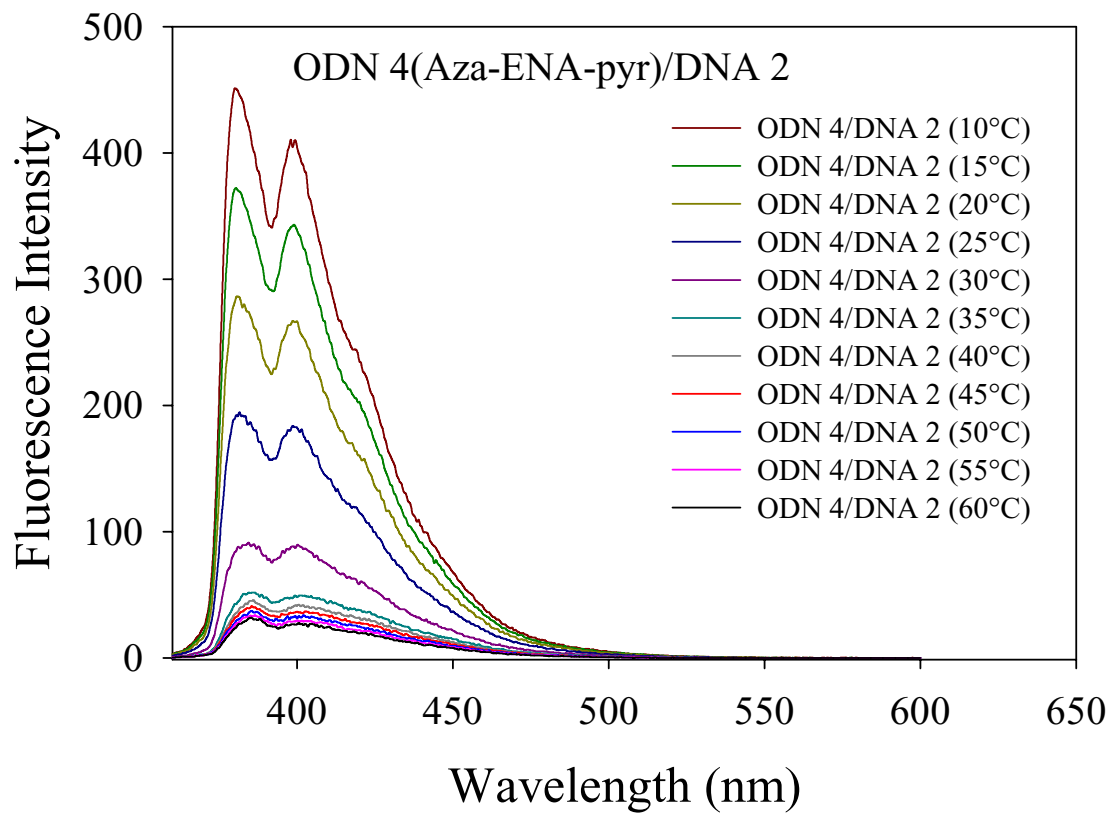

Figure S7. The emission spectra showing temperature dependent fluorescence changes for the duplex formed by Aza-ENA-pyr modified ODN 4 and complementary DNA 2. Spectra were recorded at total strand concentration of $0.8 \mu \mathrm{M}$ and with an excitation wavelength of $340 \mathrm{~nm}$. 

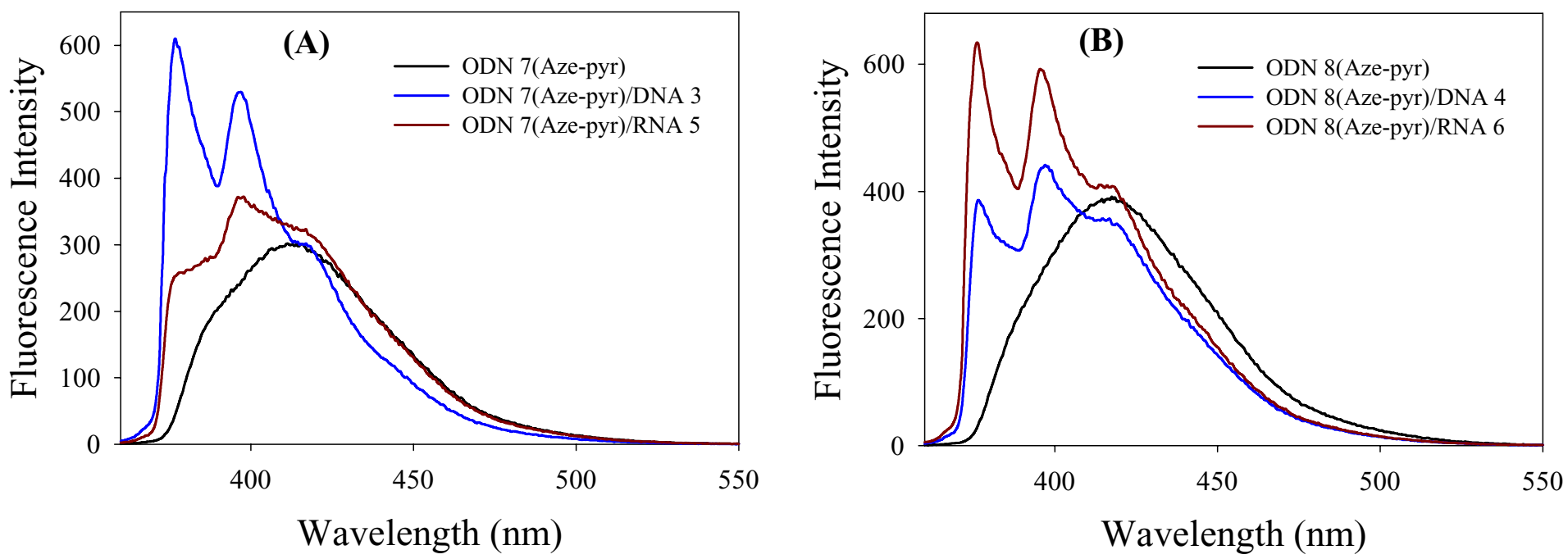

Figure S8. Fluorescence emission spectra of (A) Aze-pyr modified ODN 7 and (B) Aze-pyr modified ODN 8 and the corresponding duplexes with complementary DNA or RNA targets. Spectra were recorded at total strand concentration of $0.8 \mu \mathrm{M}$ and with an excitation wavelength of $340 \mathrm{~nm}$. 

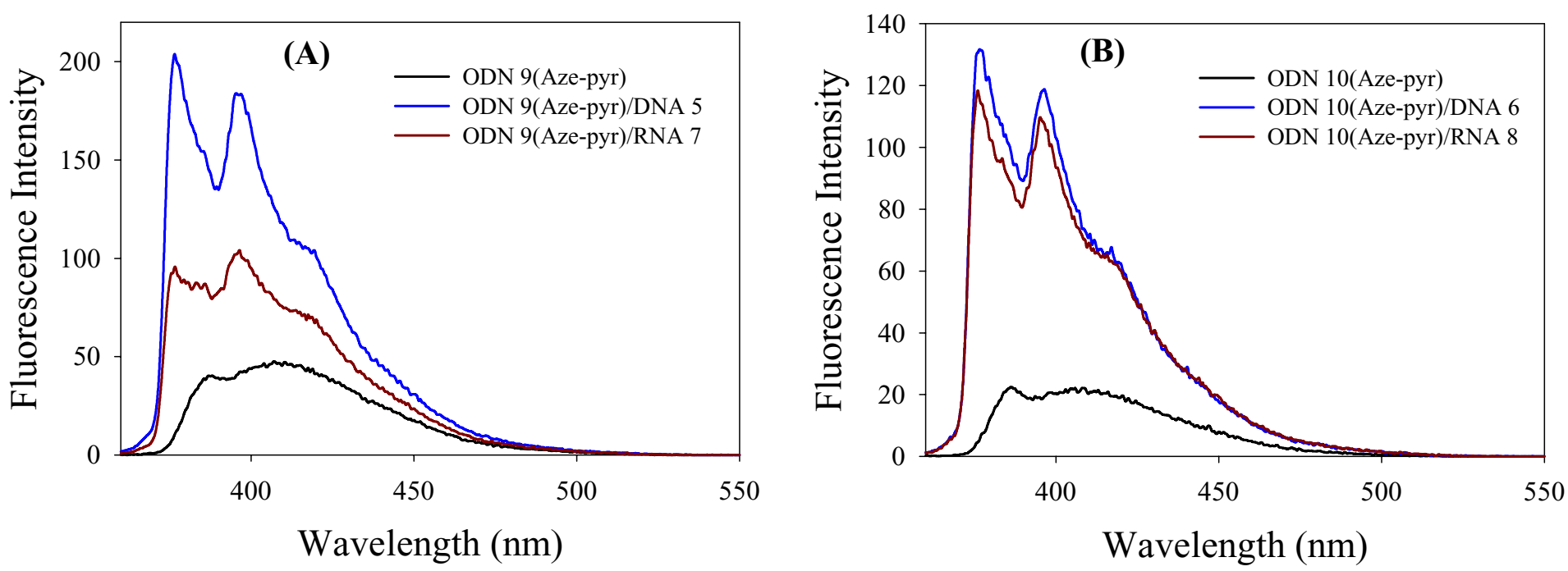

Figure S9. Fluorescence emission spectra of (A) Aze-pyr modified ODN 9 and (B) Aze-pyr modified ODN 10 and the corresponding duplexes with complementary DNA or RNA targets. Spectra were recorded at total strand concentration of $0.8 \mu \mathrm{M}$ and with an excitation wavelength of $340 \mathrm{~nm}$. 

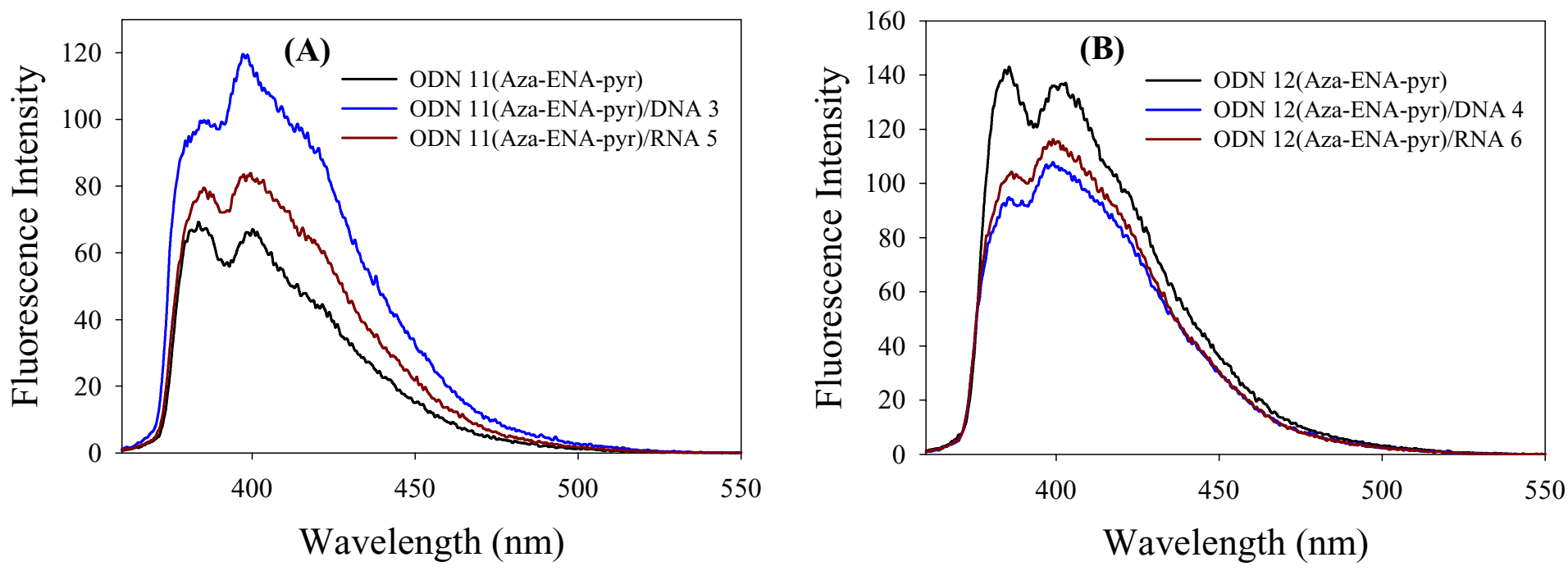

Figure S10. Fluorescence emission spectra of (A) Aza-ENA-pyr modified ODN 11 and (B) Aza-ENApyr modified ODN 12 and the corresponding duplexes with complementary DNA or RNA targets. Spectra were recorded at total strand concentration of $0.8 \mu \mathrm{M}$ and with an excitation wavelength of 340 nm. 

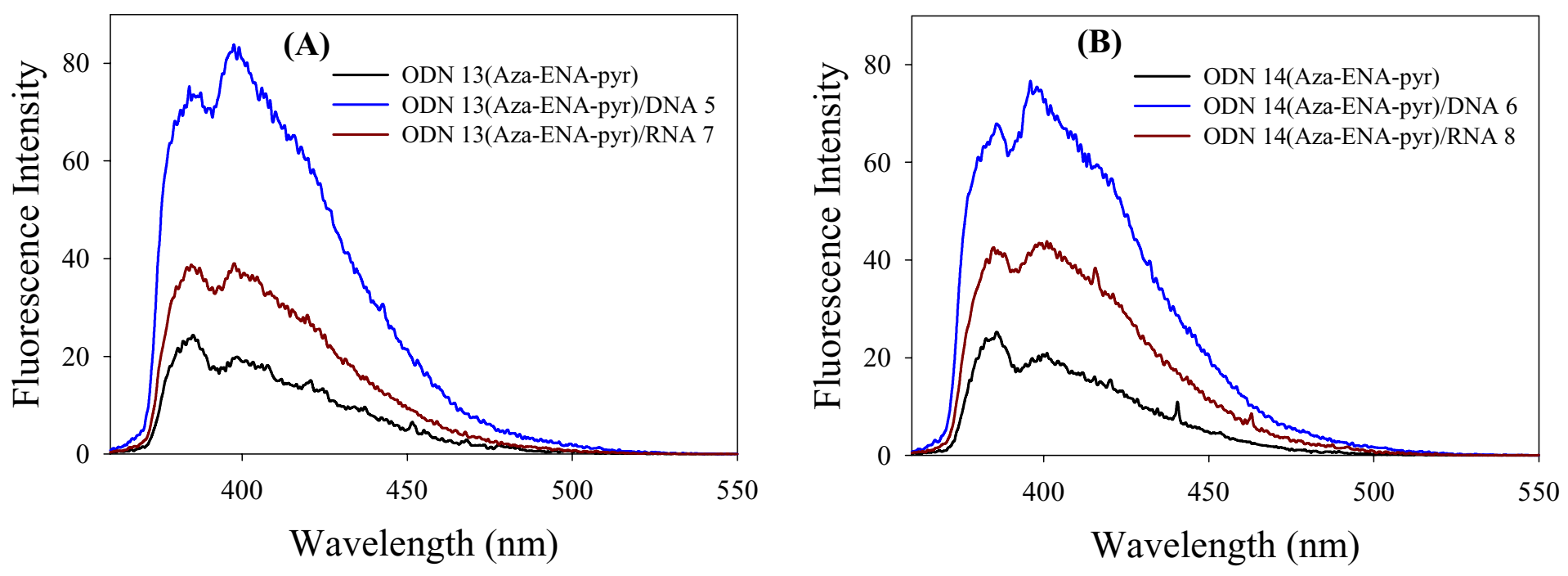

Figure S11. Fluorescence emission spectra of (A) Aza-ENA-pyr modified ODN 13 and (B) Aza-ENApyr modified ODN 14 and the corresponding duplexes with complementary DNA or RNA targets. Spectra were recorded at total strand concentration of $0.8 \mu \mathrm{M}$ and with an excitation wavelength of 340 nm. 


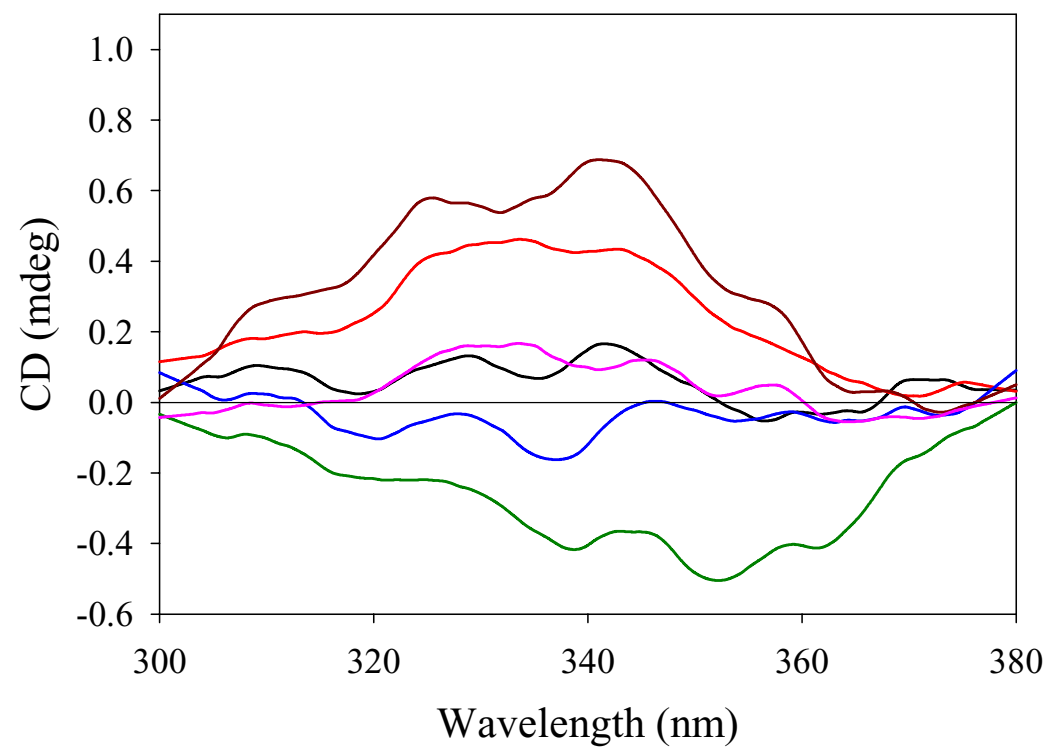

ODN 1(Aze-pyr)/DNA 2

- ODN 4(Aza-ENA-pyr)/DNA 2

ODN 1(Aze-pyr)/RNA 1 ODN 4(Aza-ENA-pyr)/RNA 1 ODN 1(Aze-pyr)/RNA 2 ODN 4(Aza-ENA-pyr)/RNA 2

Figure S12. Expanded CD spectra for the duplexes formed by Aze-pyr modified ODN 1 and AzaENA-pyr modified ODN 4 with complementary DNA 2, RNA 1 and with single base mismatch (G) RNA 2. The total strand concentration was $10 \mu \mathrm{M}$. 

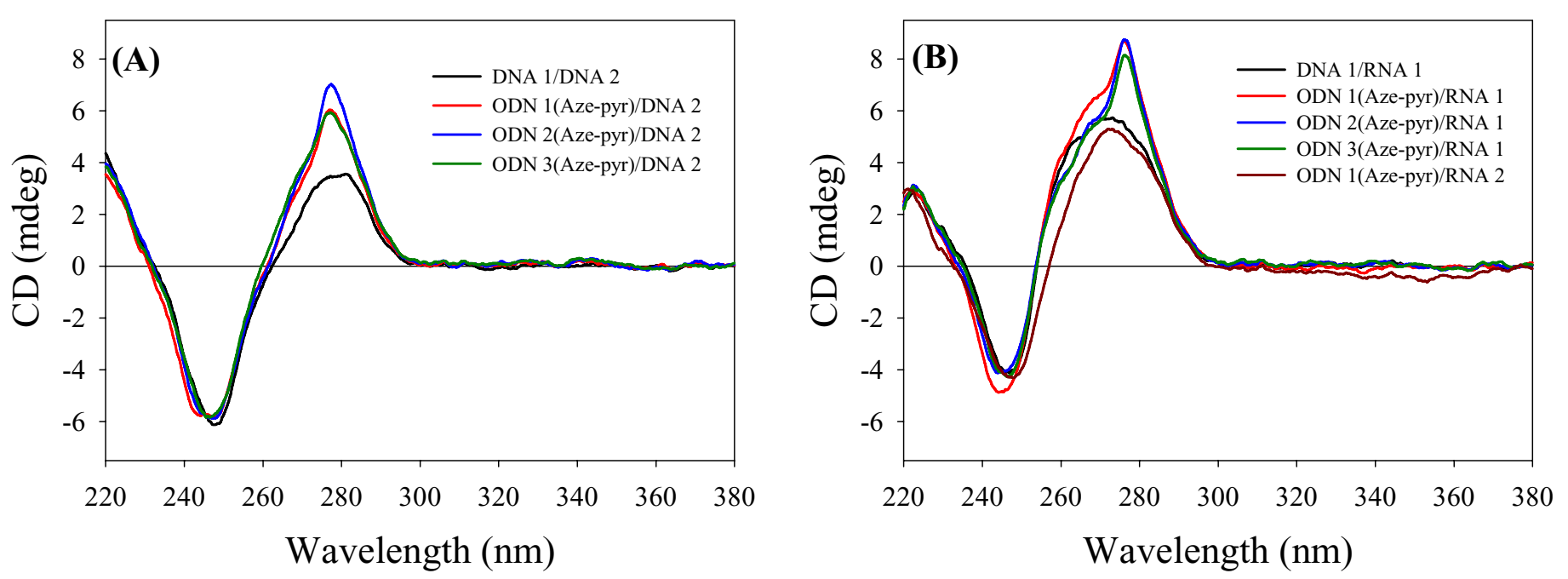

Figure S13. (A) CD spectra of duplexes formed by native DNA 1 with complementary DNA 2 and Aze-pyr modified ODNs 1-3 with complementary DNA 2. (B) CD spectra of duplexes formed by native DNA 1 with complementary RNA 1 and Aze-pyr modified ODNs 1-3 with complementary RNA 1 and with RNA 2 containing single base (G) mismatch. The total strand concentration was 10 $\mu \mathrm{M}$. 

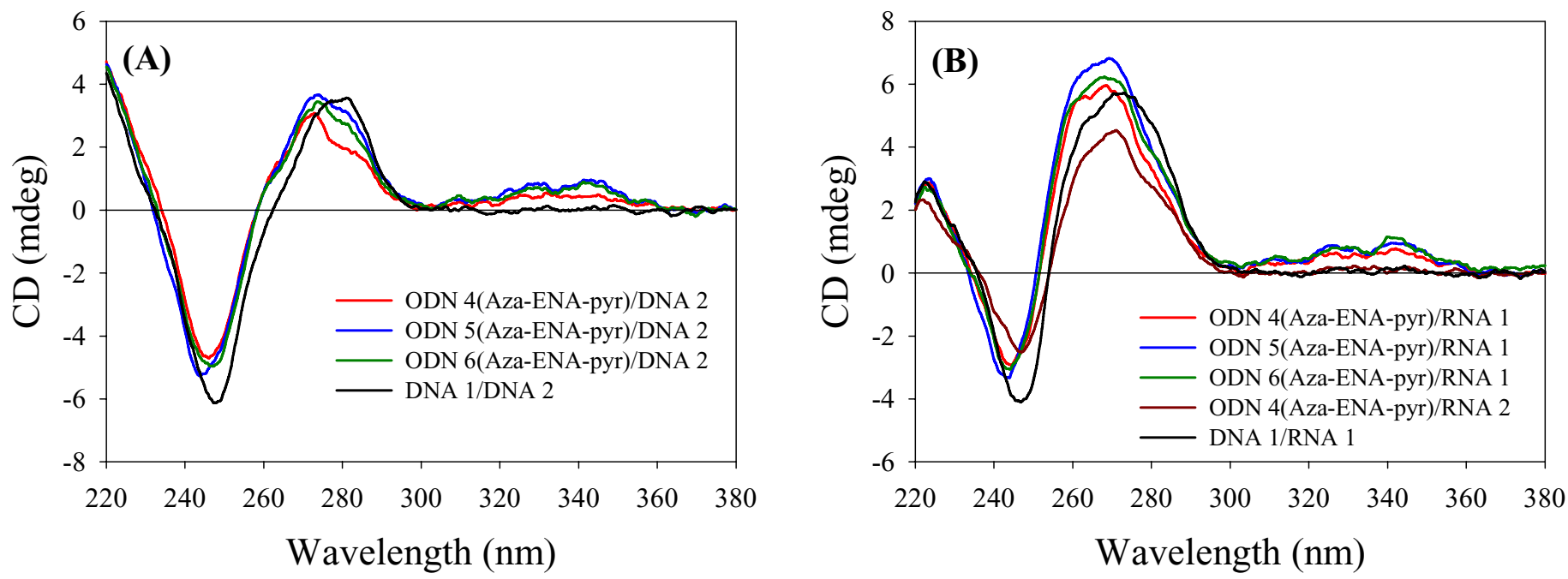

Figure S14. (A) CD spectra of duplexes formed by native DNA 1 with complementary DNA 2 and Aza-ENA-pyr modified ODNs 4-6 with complementary DNA 2. (B) CD spectra of duplexes formed by native DNA 1 with complementary RNA 1 and Aza-ENA-pyr modified ODNs 4-6 with complementary RNA 1 and with RNA 2 containing single base (G) mismatch. The total strand concentration was $10 \mu \mathrm{M}$. 

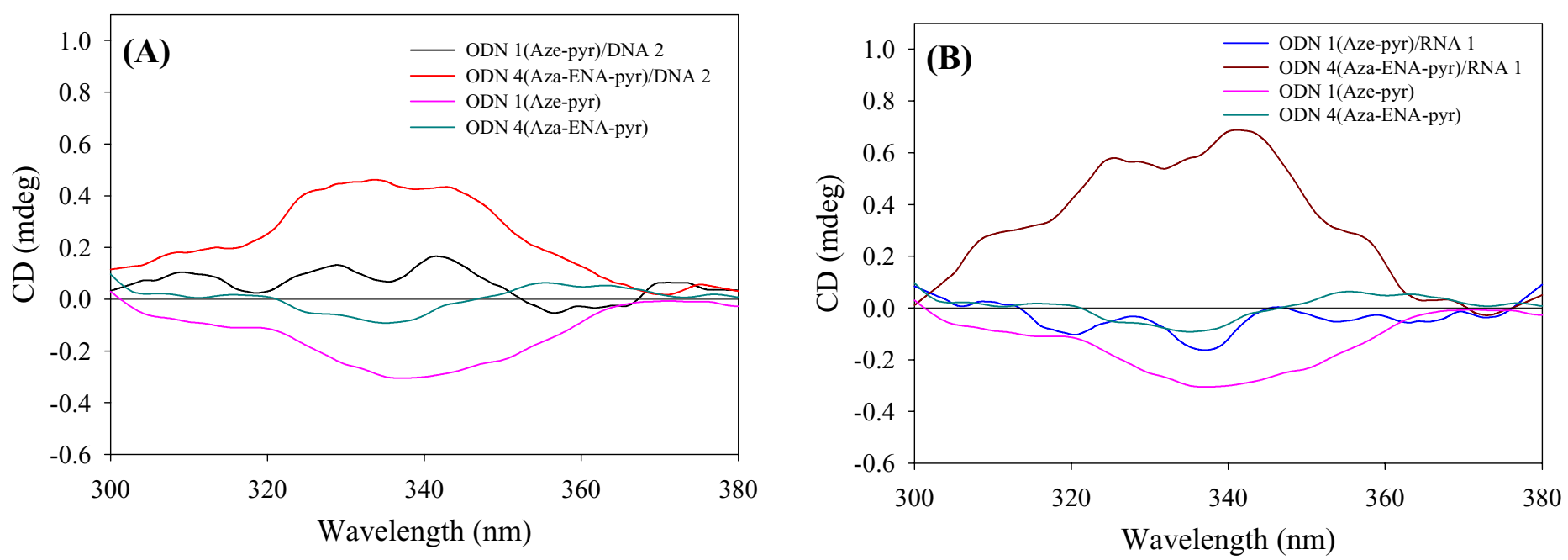

Figure S15. Expanded CD spectra of Aze-pyr modified ODN 1 and Aza-ENA-pyr modified ODN 4 and for their corresponding duplexes with (A) complementary DNA 2 and (B) complementary RNA 1. The total strand concentration was $10 \mu \mathrm{M}$. 
ก

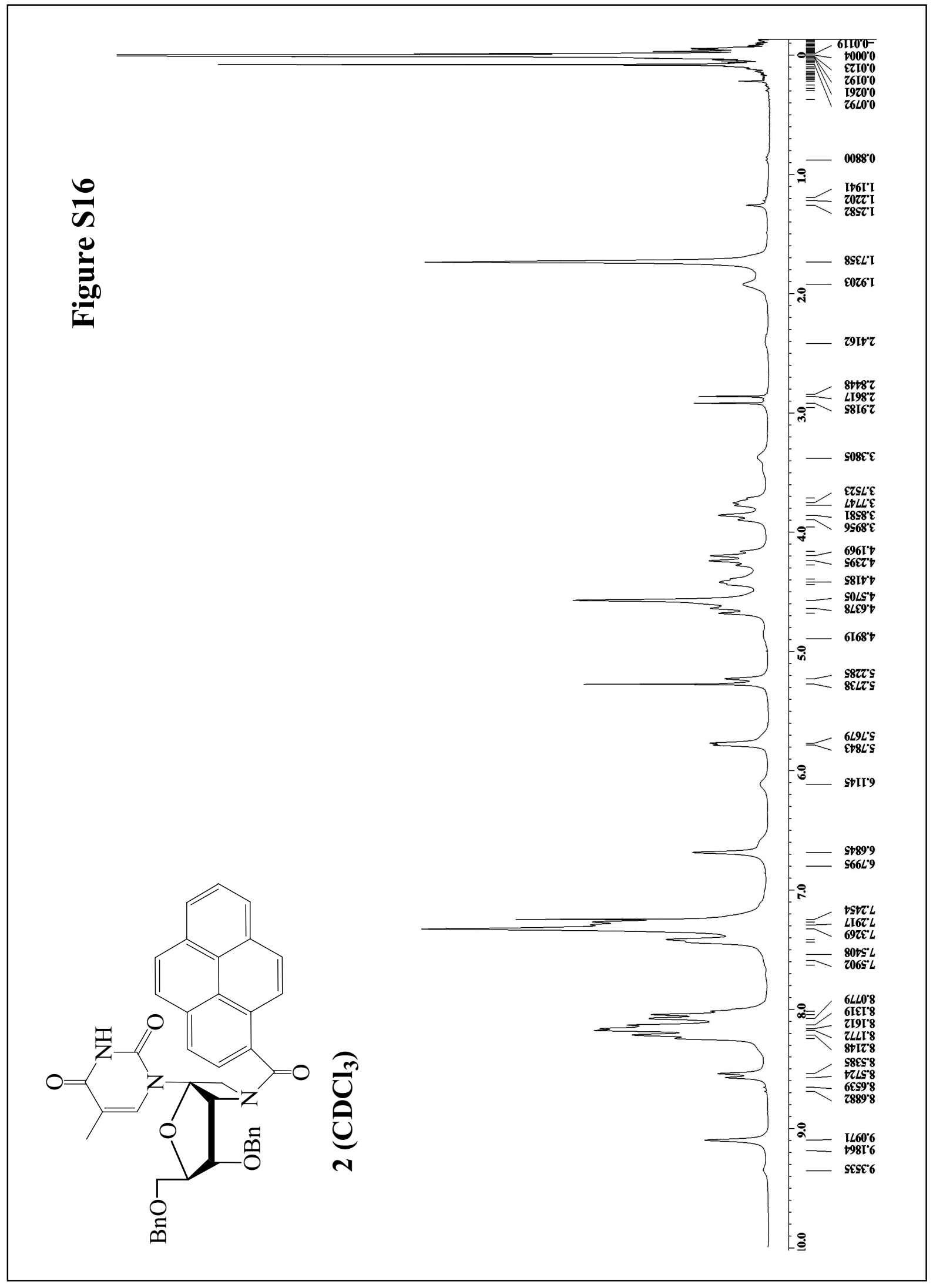


ฟั

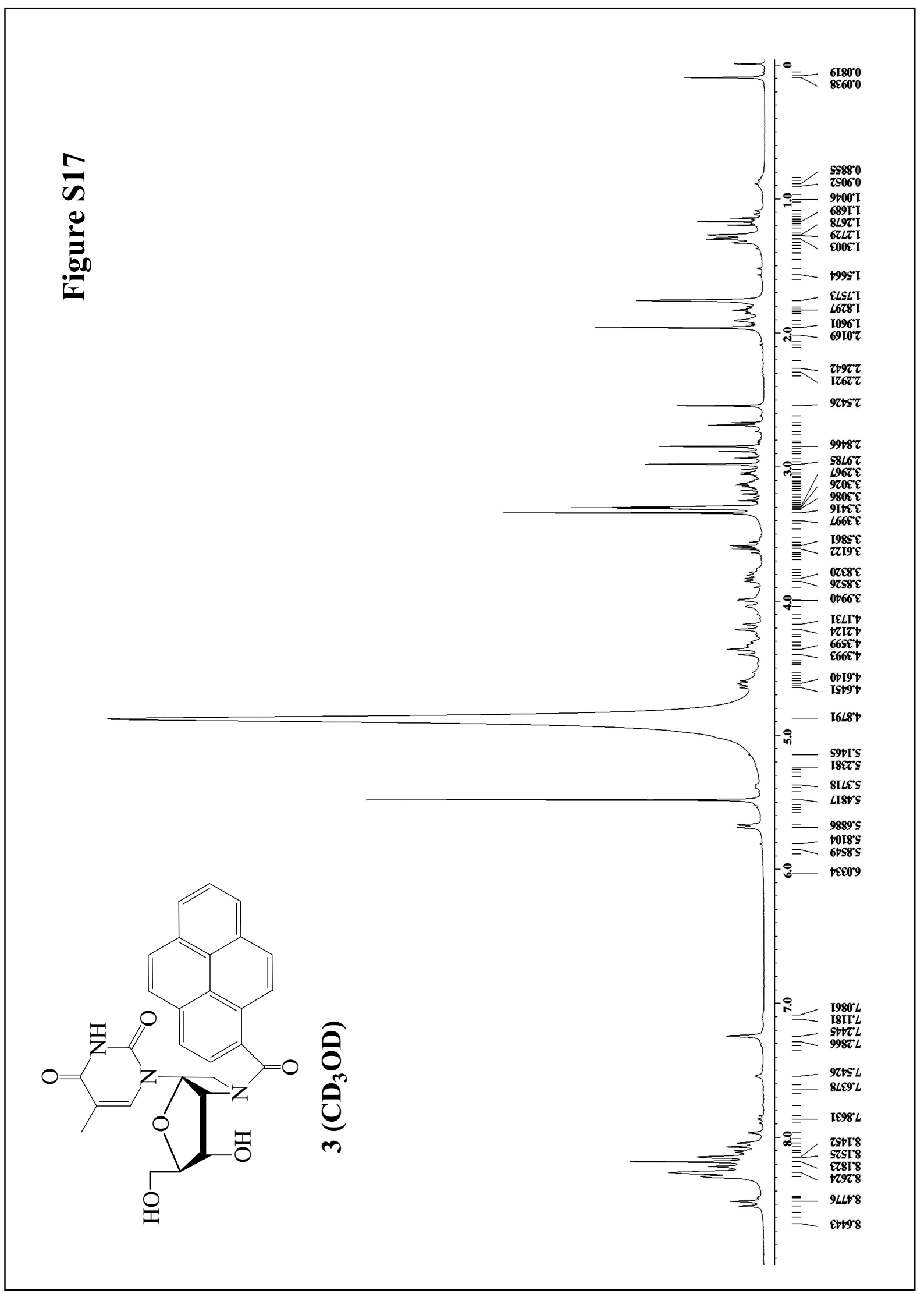


๙

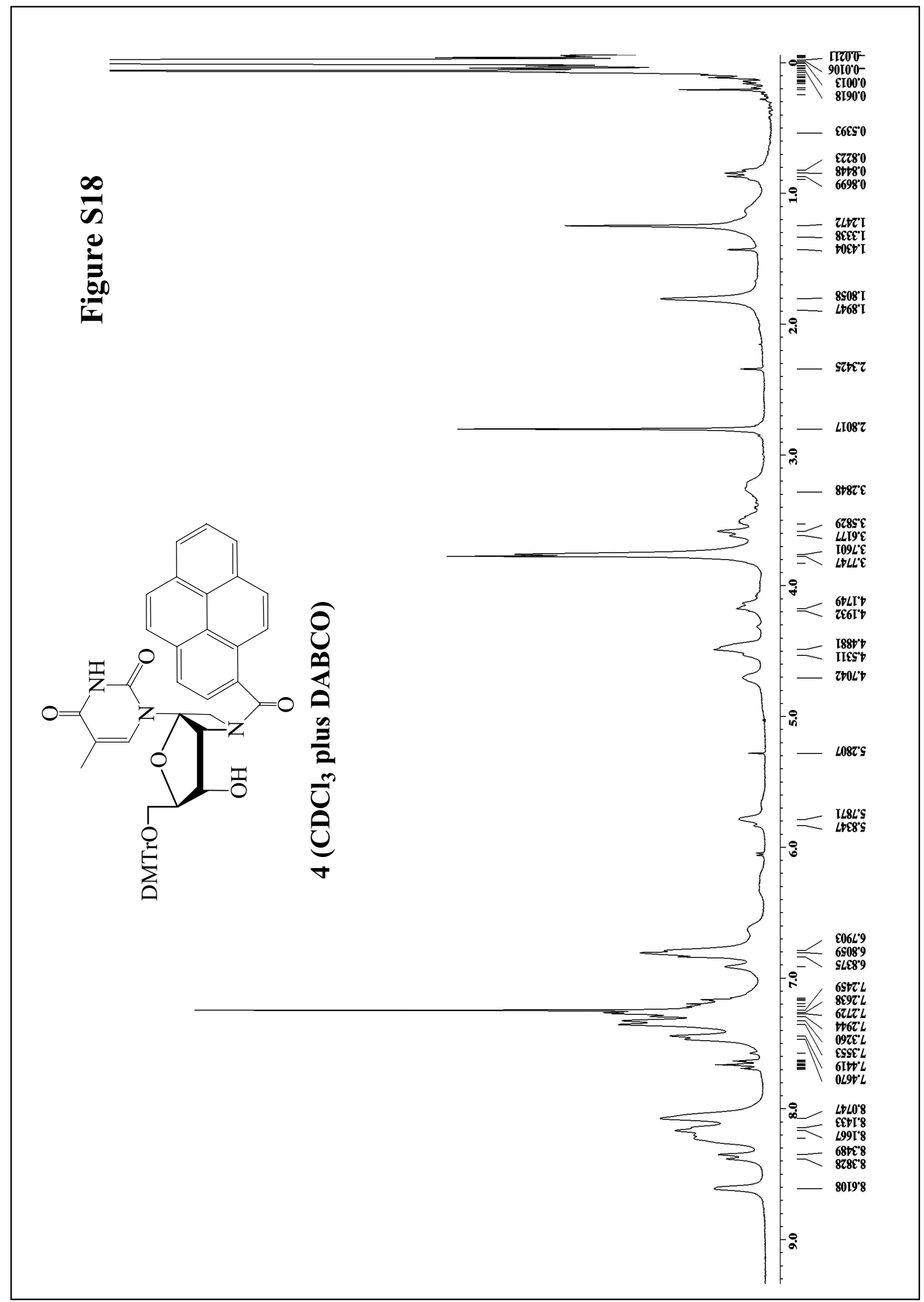


ฟै

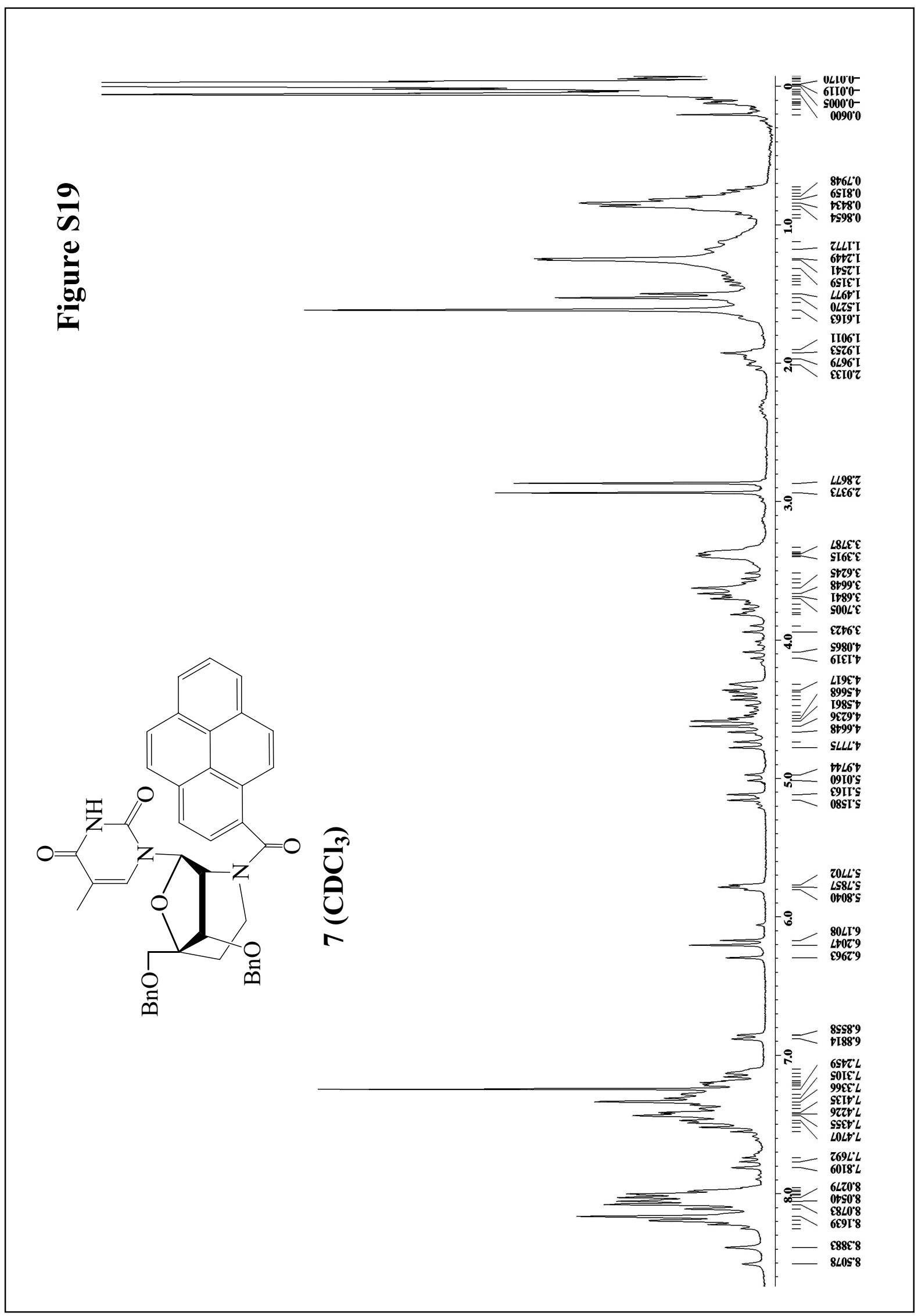




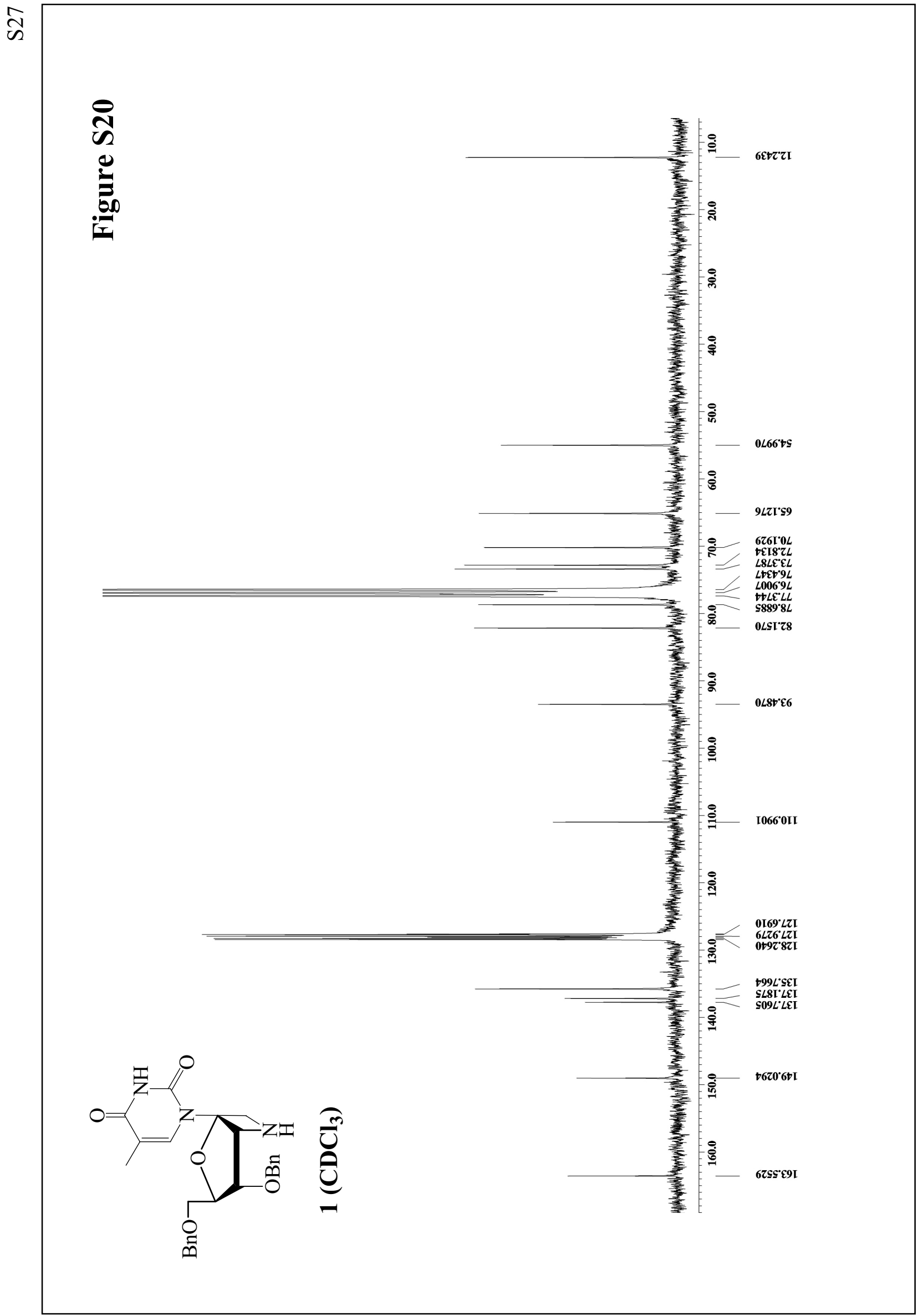




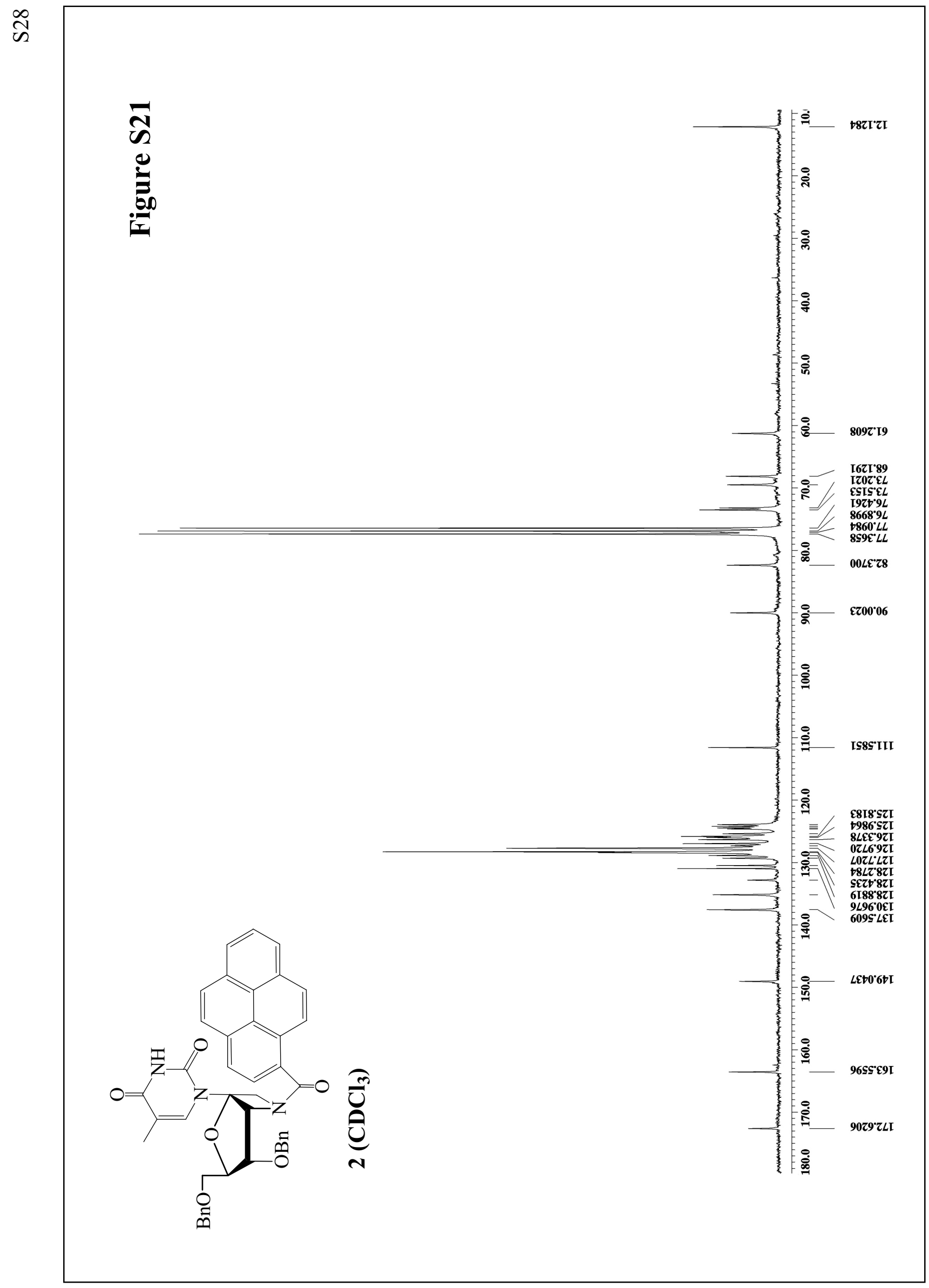




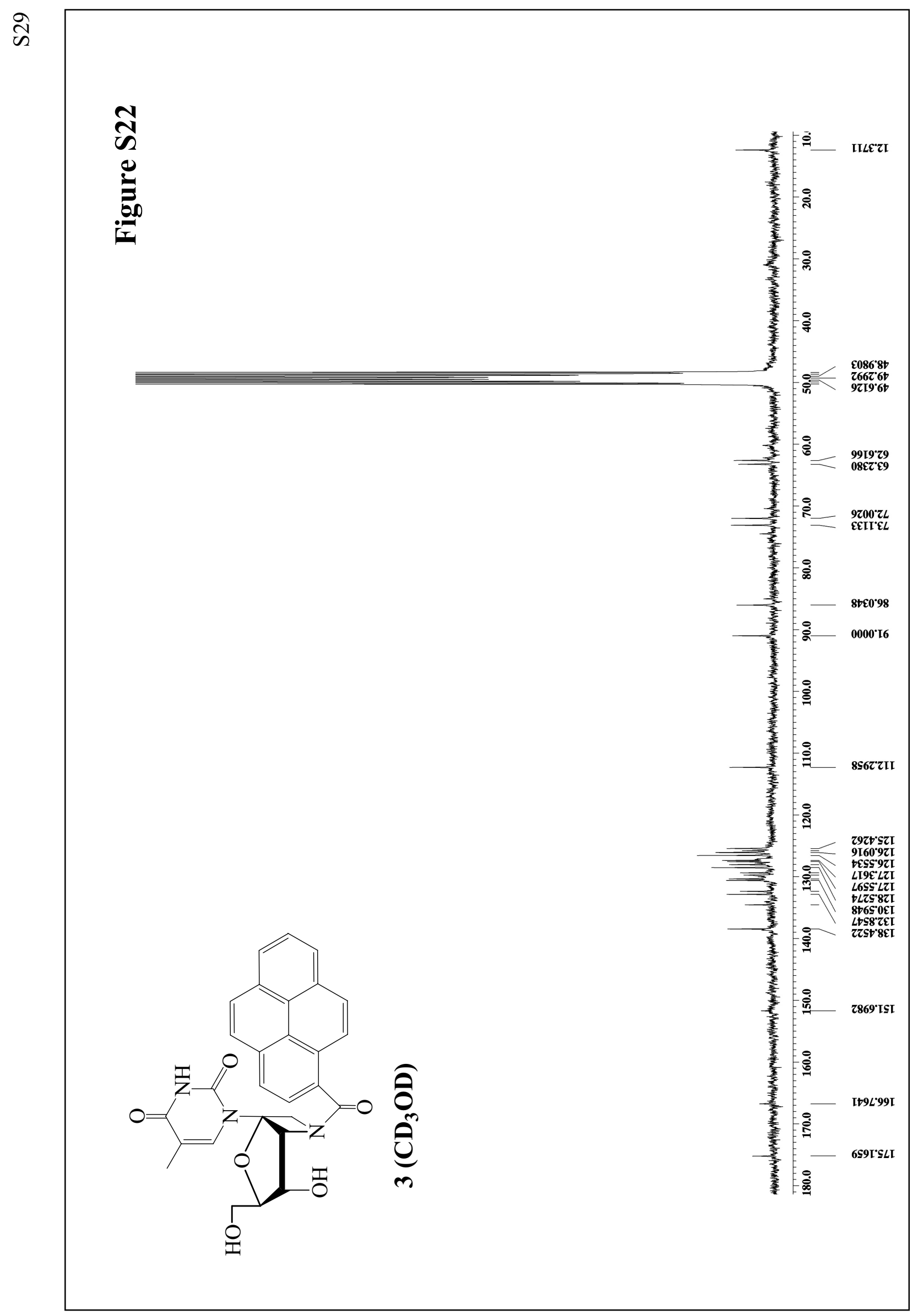




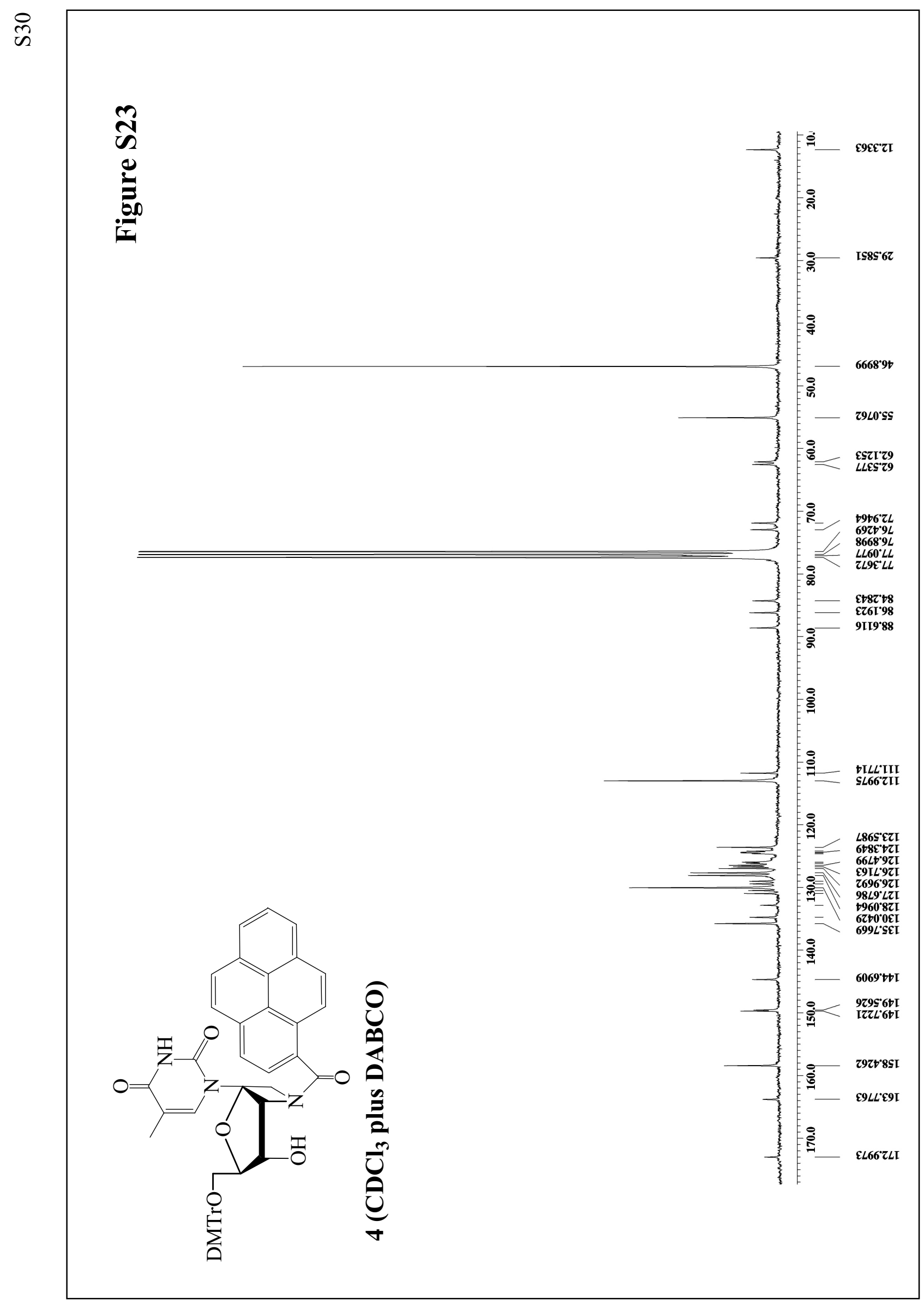


$\bar{n}$

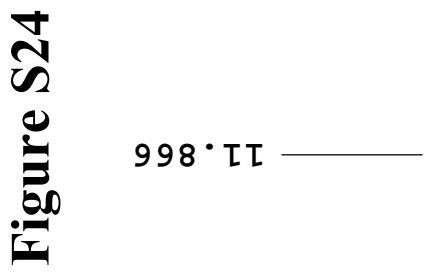

$989^{\circ} L Z$

$60 L \cdot 6 Z$

Ђโ9・8 8

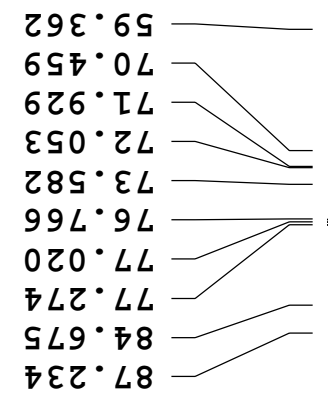

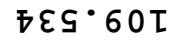

$8 \varepsilon 9^{\circ} L \tau \tau$

$008^{\circ} \angle \mathrm{LT}$

IT6 $\angle \mathrm{LI}$

$280^{\circ} 8 \mathrm{ZT}$

$0 L \tau^{\circ} 8 \mathrm{ZT}$

Ђ

$859^{\circ} 8 Z \tau$

$696^{\circ} \mathrm{s} \tau \mathrm{I}$

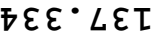

乙૬S $L \varepsilon \tau$

$\left.\varepsilon 88^{\circ} 6\right\rceil \tau$

$\tau 89^{\circ} \varepsilon 9 \tau$

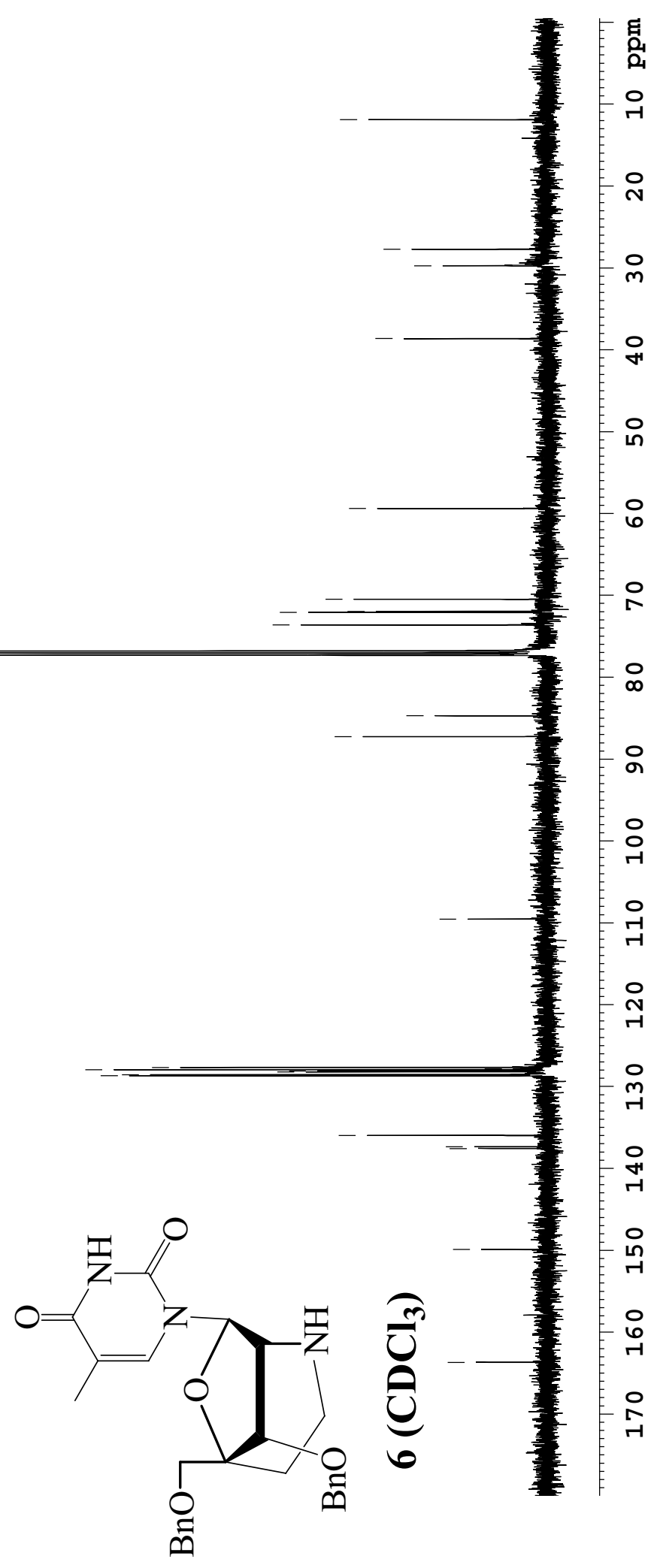


กิ

ชิ
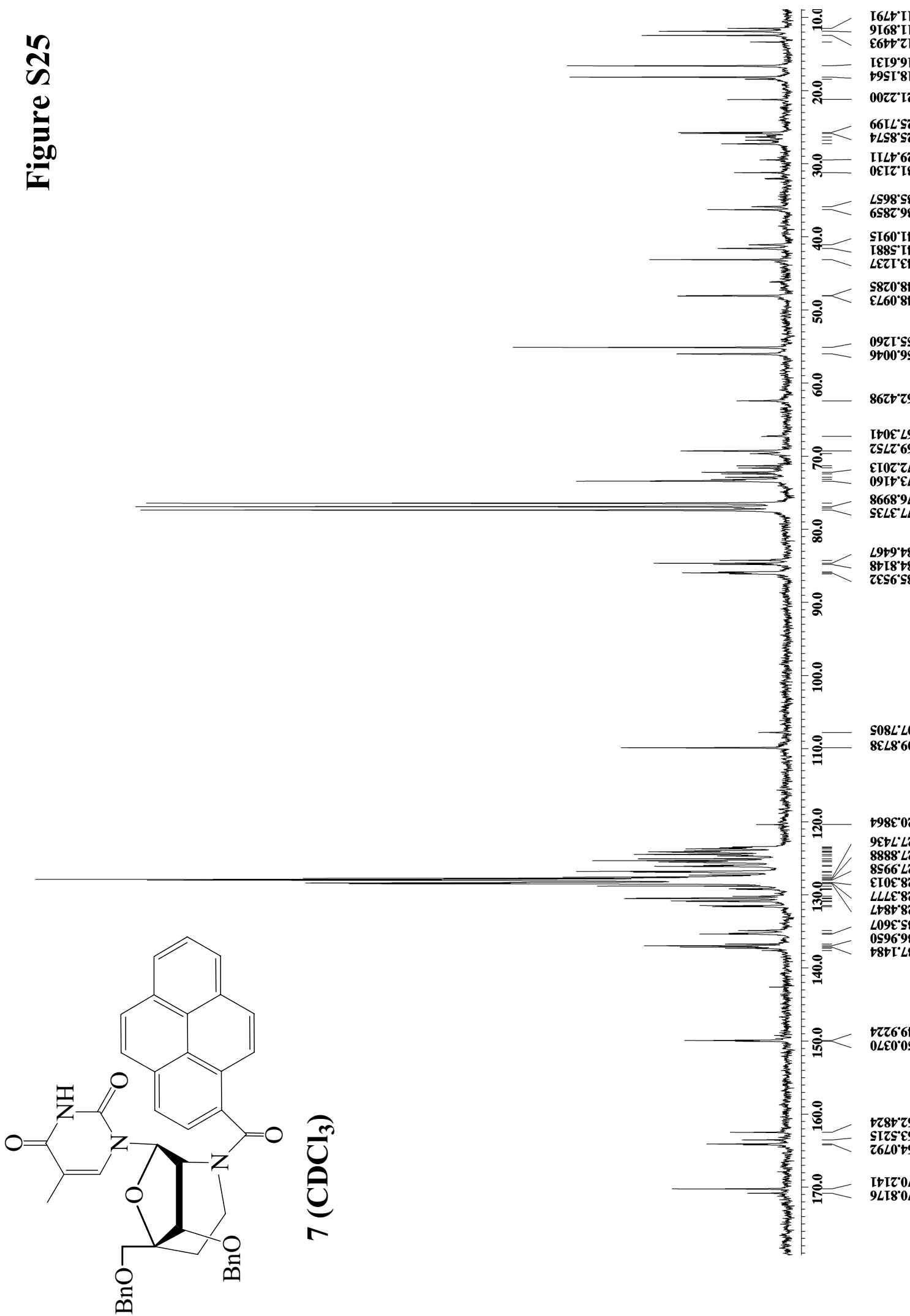

$\underbrace{0}$

S08LLOI 8EL860I

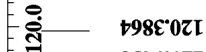
$9 \varepsilon t \angle \circ L z I$ $\mathbf{8 8 8 8}^{\circ} \angle Z$ L $8566 L Z$ ELOE:8zI L $485^{\circ} 8 \mathrm{I}$ L09E SEI $05969 \varepsilon$ เ8tI $\angle \mathcal{E} I$

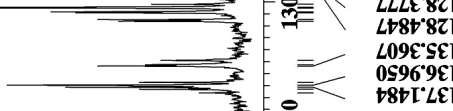




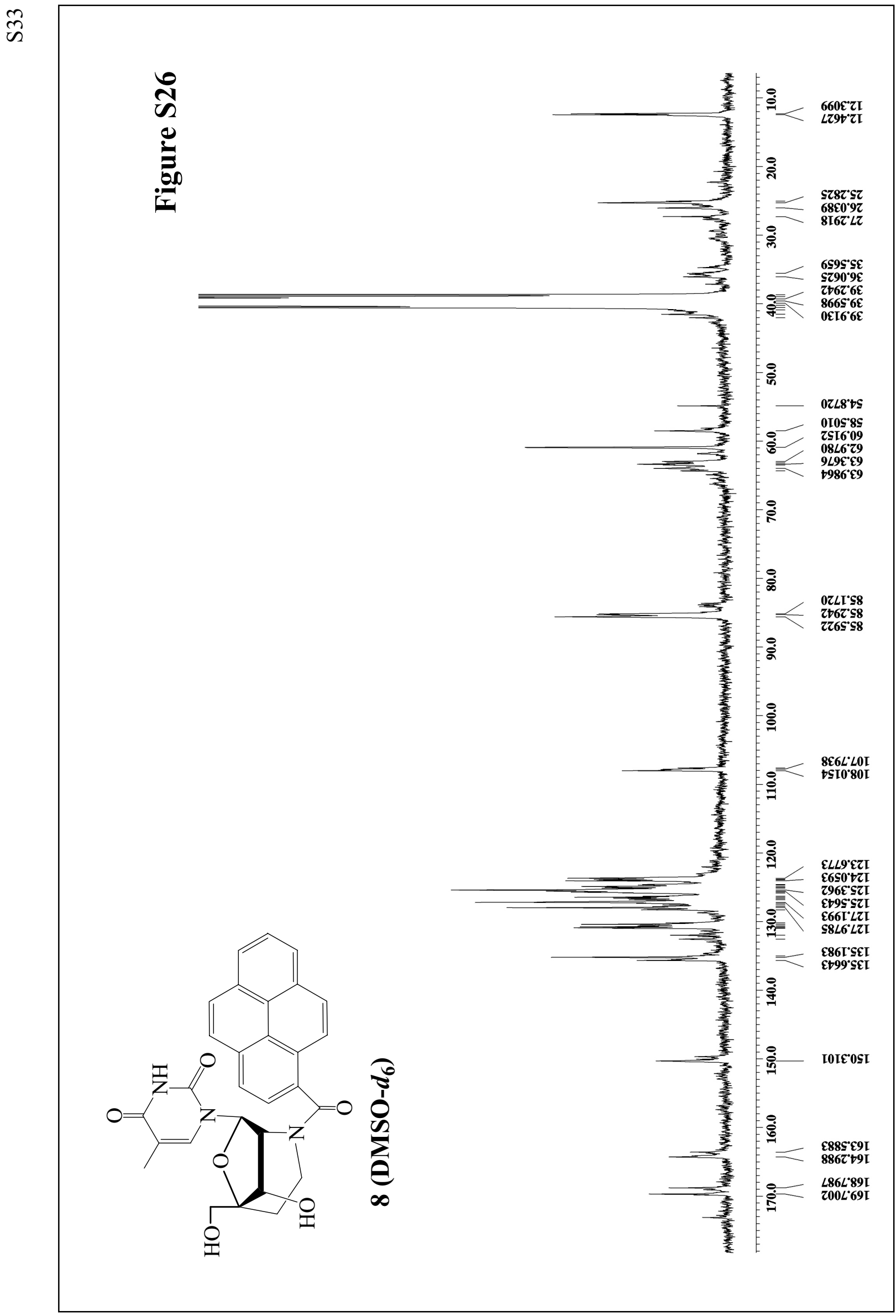


落

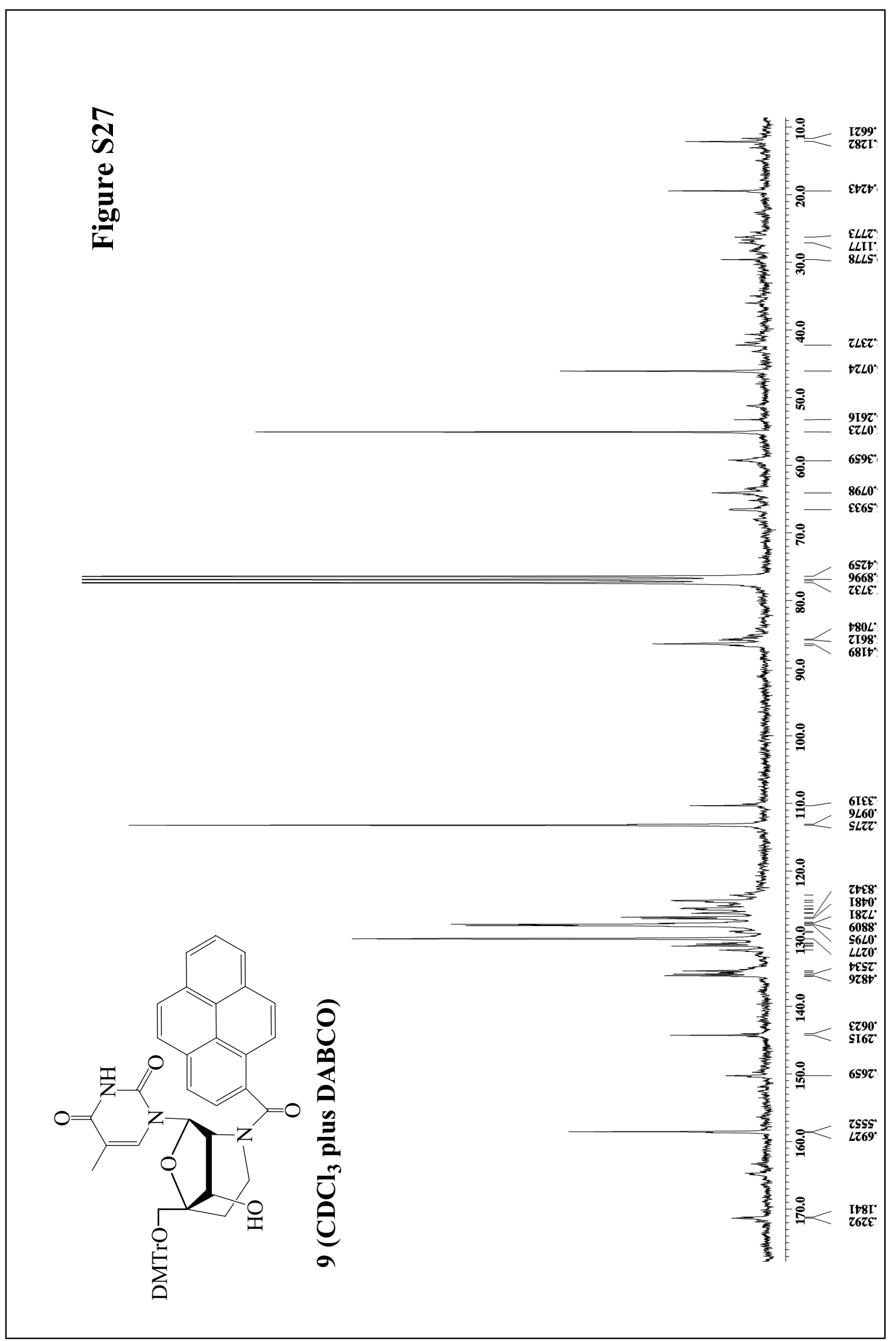


ñ

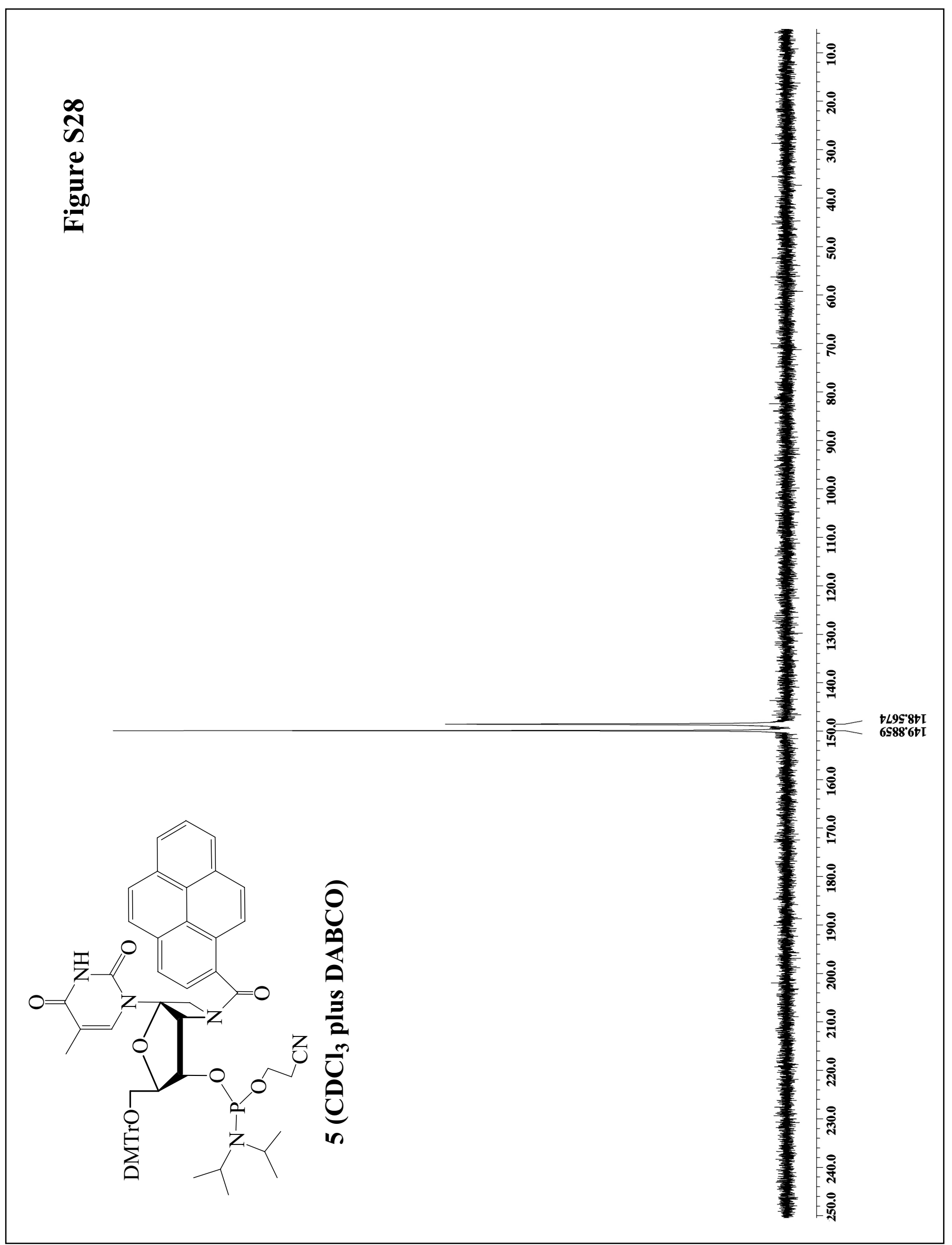




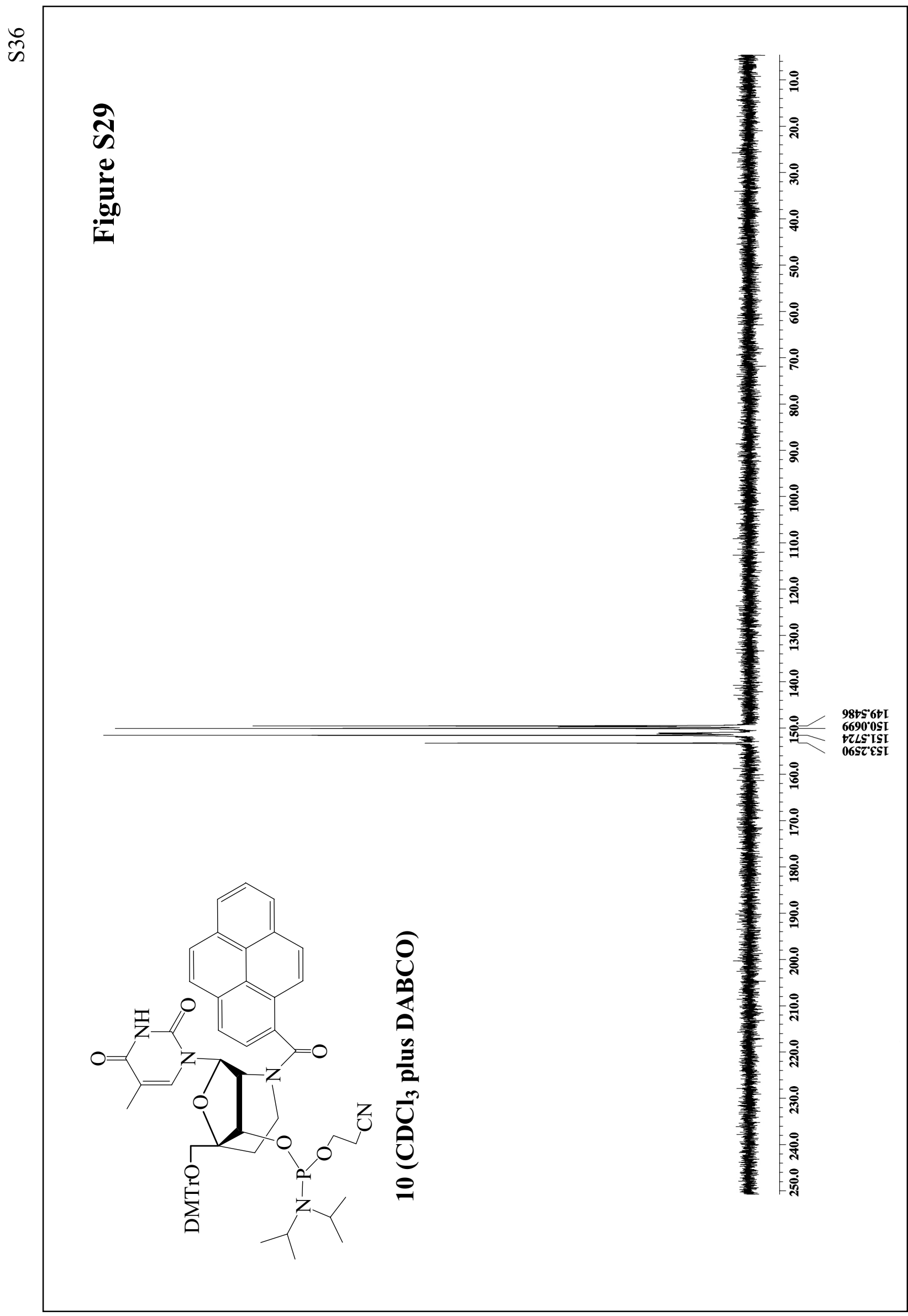

